\title{
Seasonal patterns in phytoplankton photosynthetic parameters and primary production at a coastal NW Mediterranean site
}

\author{
Josep M. Gasol ${ }^{1}$, Clara Cardelús ${ }^{1}$, Xosé Anxelu G. Morán ${ }^{2}$, Vanessa Balagué ${ }^{1}$, Irene Forn ${ }^{1}$, \\ Cèlia Marrasé ${ }^{1}$, Ramon Massana ${ }^{1}$, Carlos Pedrós-Alió ${ }^{1,3}$, M. Montserrat Sala ${ }^{1}$, \\ Rafel Simó ${ }^{1}$, Dolors Vaqué ${ }^{1}$, Marta Estrada ${ }^{1}$ \\ ${ }^{1}$ Institut de Ciències del Mar, Pg. Marítim de la Barceloneta, 37-49, 08003 Barcelona, Catalunya, Spain. \\ E-mail: pepgasol@icm.csic.es \\ ${ }^{2}$ King Abdullah University of Science and Technology, Red Sea Research Centre, Biological and Environmental Sciences \\ and Engineering Division, Thuwal, Saudi Arabia. \\ ${ }^{3}$ present address: Systems and Synthetic Biology Programme, Centro Nacional de Biotecnología, CSIC, Cantoblanco, \\ Madrid, Spain
}

\begin{abstract}
Summary: We carried out monthly photosynthesis-irradiance (P-E) experiments with the ${ }^{14} \mathrm{C}$-method for 12 years $(2003-$ 2014) to determine the photosynthetic parameters and primary production of surface phytoplankton in the Blanes Bay Microbial Observatory, a coastal sampling station in the NW Mediterranean Sea. Our goal was to obtain seasonal trends and to establish the basis for detecting future changes of primary production in this oligotrophic area. The maximal photosynthetic rate $\mathrm{P}^{\mathrm{B}}{ }_{\text {max }}$ ranged 30 -fold $\left(0.5-15 \mathrm{mg} \mathrm{C} \mathrm{mg} \mathrm{Chl} a^{-1} \mathrm{~h}^{-1}\right)$, averaged $3.7 \mathrm{mg} \mathrm{C} \mathrm{mg} \mathrm{Chl} a^{-1} \mathrm{~h}^{-1}( \pm 0.25 \mathrm{SE})$ and was highest in August and lowest in April and December. We only observed photoinhibition twice. The initial or light-limited slope of the $\mathrm{P}-\mathrm{E}$ relationship, $\alpha^{\mathrm{B}}$, was low, averaging $0.007 \mathrm{mg} \mathrm{C} \mathrm{mg} \mathrm{Chl} a^{-1} \mathrm{~h}^{-1}$ (umol photons $\left.\mathrm{m}^{-2} \mathrm{~s}^{-1}\right)^{-1}( \pm 0.001 \mathrm{SE}$, range $0.001-0.045)$ and showed the lowest values in spring (April-June). The light saturation parameter or saturation irradiance, $\mathrm{E}_{\mathrm{K}}$, averaged $711 \mu \mathrm{mol}$ photons $\mathrm{m}^{-2} \mathrm{~s}^{-1}( \pm 58.4 \mathrm{SE})$ and tended to be higher in spring and lower in winter. Phytoplankton assemblages were typically dominated by picoeukaryotes in early winter, diatoms in late autumn and late winter, dinoflagellates in spring and cyanobacteria in summer. Total particulate primary production averaged $1.45 \mathrm{mg} \mathrm{C} \mathrm{m}^{-3} \mathrm{~h}^{-1}( \pm 0.13 \mathrm{SE})$ with highest values in winter (up to $8.50 \mathrm{mg} \mathrm{C} \mathrm{m}^{-3} \mathrm{~h}^{-1}$ ) and lowest values in summer (summer average, $0.30 \mathrm{mg} \mathrm{C} \mathrm{m}^{-3} \mathrm{~h}^{-1}$ ), while chlorophyll-

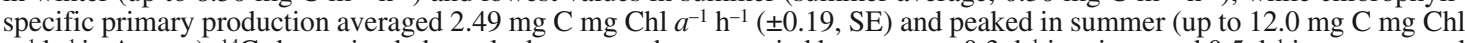
$a^{-1} \mathrm{~h}^{-1}$ in August). ${ }^{14} \mathrm{C}$-determined phytoplankton growth rates varied between ca. $0.3 \mathrm{~d}^{-1}$ in winter and $0.5 \mathrm{~d}^{-1}$ in summer and were within 60-80\% of the maximal rates of growth, based on $\mathrm{P}_{\text {max }}$. Chlorophyll $a$ was a good predictor of primary production only in the winter and autumn. Seasonality appeared to explain most of the variability in the studied variables, while phytoplankton composition played a minor role. Daily integrated primary production was fairly constant throughout the year: similar to previous oxygen-based estimates in winter but considerably lower than these in summer. The difference between ${ }^{14} \mathrm{C}$ - and oxygen-based estimates of primary production could be explained by community respiration. Annually integrated primary production amounted to a rather modest $48 \mathrm{~g} \mathrm{C} \mathrm{m}^{-2} \mathrm{yr}^{-1}$ (equivalent to $130 \mathrm{mg} \mathrm{C} \mathrm{m}^{-2} \mathrm{~d}^{-1}$ ). Although no interannual patterns were detected, our work soundly establishes the seasonal trends for the coastal NW Mediterranean, therefore setting the basis for future detection of change.
\end{abstract}

Keywords: coastal time-series station, primary production, seasonality, photosynthetic parameters, $\mathrm{P}_{\max }^{\mathrm{B}}, \alpha^{\mathrm{B}}$

Regularidades estacionales en la producción primaria y los parámetros fotosintéticos en una estación costera del NO Mediterráneo

Resumen: Hemos llevado a cabo mediciones mensuales de la relación entre fotosíntesis e irradiancia (curvas P-E) con el método del ${ }^{14} \mathrm{C}$ durante 12 años (2003-2014), para obtener los parámetros fotosintéticos y la producción primaria del fitoplancton superficial en el Observatorio Microbiano de la Bahía de Blanes, una estación de muestreo costera en el noroeste del Mediterráneo. Nuestro objetivo era determinar las tendencias estacionales y establecer la línea de base para detectar cambios futuros de la producción primaria en esta área oligotrófica. La tasa fotosintética máxima $\mathrm{P}^{\mathrm{B}}$ max osciló 30 veces $(0.5 \mathrm{a} 15 \mathrm{mg}$ $\left.\mathrm{C} \mathrm{mg} \mathrm{Chl} a^{-1} \mathrm{~h}^{-1}\right)$, con un promedio de $3.7 \mathrm{mg} \mathrm{C} \mathrm{mg} \mathrm{Chl} a^{-1} \mathrm{~h}^{-1}( \pm 0.25$, error estándar), y fue máxima en agosto y mínima en abril y diciembre. Sólo se observó fotoinhibicion dos veces. La pendiente inicial de la curva P-E, $\alpha^{\mathrm{B}}$, fue baja, con un

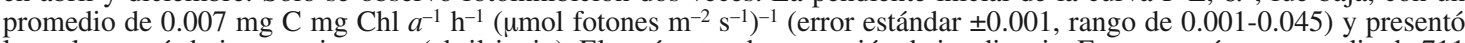
los valores más bajos en primavera (abril-junio). El parámetro de saturación de irradiancia, $\mathrm{E}_{\mathrm{K}}$, presentó un promedio de 711 $u \mathrm{~mol}$ fotones $\mathrm{m}^{-2} \mathrm{~s}^{-1}( \pm 58.4$, error estándar) y tendió a ser mayor en primavera y menor en invierno. El fitoplancton estuvo típicamente dominado por picoeucariotas a principios de invierno, diatomeas a finales de otoño y en el invierno avanzado, dinoflagelados en primavera, y cianobacterias en verano. La producción primaria particulada total promedió $1.45 \mathrm{~m}^{-3} \mathrm{~h}^{-1}$ ( \pm 0.13 error estándar) con máximos en invierno (hasta $8.50 \mathrm{mg} \mathrm{C} \mathrm{m}^{-3} \mathrm{~h}^{-1}$ ) y mínimos en verano (media en verano, $0.30 \mathrm{mg}$ $\left.\mathrm{C} \mathrm{m}^{-3} \mathrm{~h}^{-1}\right)$, mientras que la producción primaria por unidad de clorofila promedió $2.49 \mathrm{mg} \mathrm{C} \mathrm{mg} \mathrm{Chl} a^{-1} \mathrm{~h}^{-1}( \pm 0.19$, error estándar) y alcanzó su punto máximo en verano (hasta $12.0 \mathrm{mg} \mathrm{C} \mathrm{mg} \mathrm{Chl} a^{-1} \mathrm{~h}^{-1}$ en agosto). Las tasas de crecimiento del 
fitoplancton determinadas por ${ }^{14} \mathrm{C}$ oscilaron entre ca. $0.3 \mathrm{~d}^{-1}$ en invierno y $0.5 \mathrm{~d}^{-1}$ en verano, siendo $60-80 \%$ de las tasas máximas de crecimiento basadas en los valores de $\mathrm{P}^{\mathrm{B}}{ }_{\max }$. La clorofila $a$ resultó ser un buen predictor de la producción primaria sólo en el invierno y el otoño. La estacionalidad explica la mayor parte de la variabilidad en las variables estudiadas, mientras que la composición del fitoplancton juega un papel menor. La producción primaria integrada diaria fue bastante constante durante todo el año, similar a estimaciones anteriores con mediciones de oxígeno en invierno, pero considerablemente más bajas en verano. La diferencia entre las estimaciones de la producción primaria por ${ }^{14} \mathrm{C}$ y las estimaciones en base al oxígeno podrían explicarse por la respiración de la comunidad. Anualmente la producción primaria integrada ascendió a valores más bien modestos de $48 \mathrm{~g} \mathrm{C} \mathrm{m}^{-2}$ año-1 (equivalentes a $130 \mathrm{mg} \mathrm{C} \mathrm{m}^{-2} \mathrm{~d}^{-1}$ ). Aunque no se detectaron patrones interanuales, nuestro trabajo establece las tendencias estacionales para la producción primaria en el litoral Mediterráneo noroccidental, y supone la línea de base para la detección de cambios futuros.

Palabas clave: estacion costera a largo término, producción primaria, estacionalidad, parámetros fotosintéticos, $\mathrm{P}^{\mathrm{B}}{ }_{\max }, \alpha^{\mathrm{B}}$

Citation/Como citar este artículo: Gasol J.M., Cardelús C., Morán X.A.G., Balagué V., Forn I., Marrasé C., Massana R., Pedrós-Alió C., Sala M.M., Simó R., Vaqué D., Estrada M. 2016. Seasonal patterns in phytoplankton photosynthetic parameters and primary production at a coastal NW Mediterranean site. Sci. Mar. 80S1: 63-77. doi: http://dx.doi.org/10.3989/ scimar.04480.06E

Editor: J.L. Pelegrí.

Received: May 23, 2016. Accepted: August 13, 2016. Published: September 30, 2016.

Copyright: (c) 2016 CSIC. This is an open-access article distributed under the terms of the Creative Commons Attribution (CC-by) Spain 3.0 License.

\section{INTRODUCTION}

Phytoplankton primary production is a fundamental ecosystem service provided by the ocean that amounts to about half of the biosphere's synthesis of organic matter (Field et al. 1998) and fuels marine food webs. In addition, primary production affects oxygen and $\mathrm{CO}_{2}$ fluxes between the ocean and the atmosphere.

Various methods are used to estimate primary production (e.g. ${ }^{18} \mathrm{O}_{2}, \mathrm{O}_{2}$ or $\mathrm{CO}_{2}$ evolution, ${ }^{14} \mathrm{C}$ ), each with its own drawbacks (Marra 2002, Regaudie-de-Gioux et al. 2014). They are comparable but not really proportional, as each methodology measures a different photosynthetic or metabolic process (e.g. Platt and Sathayendranath 1993, Regaudie-de-Gioux et al. 2014). Given the relative difficulties associated with measuring primary production with either the widespread ${ }^{14} \mathrm{C}$ method introduced by Steemen-Nielsen in 1952 (Steeman-Nielsen 1952) or any of the existing alternative methods, this rate is often estimated from chlorophyll levels, though it is likely incorrect in coastal oceanic regions, particularly if the natural range of variation of chlorophyll is small. The measurement of photosynthesis at a series of irradiance levels in a water incubator with a gradient of light (the so called photosynthesisirradiance relationship or P-E curve) has the advantage of providing a description of the photophysiology (photoadaptation and photosynthetic capacity) of the involved algal communities and allows the rapid assessment of how it varies seasonally or spatially in response to light availability and the phytoplankton types involved (Sakshaug et al. 1997). It can also be used to model scenarios of changing underwater light climate and how the changes are reflected in the amount of fixed carbon.

While primary production has been measured continuously for several years in some long-term ecological stations using ${ }^{14} \mathrm{C}$, as in BATS and HOT (Steinberg et al. 2001; Karl and Church 2014), or by $\mathrm{O}_{2}$ evolution in the Blanes Bay Microbial Observatory (Duarte et al. 2004), very seldom have the parameters of the P-E curve been studied seasonally and interannually.
Exceptions exist: for instance, Gallegos (2012) studied the Rhode River weekly for ca. 20 years and Tillmann et al. (2000) studied the Wadden Sea for 2 years. Finenko et al. (2002) studied the different seasons during different years in the Black Sea. One-year studies are available for more sites, such as the Bay of Biscay (Morán 2007, Morán and Scharek 2015) and the Tagus estuary (Gameiro et al. 2011). Yet the seasonality of the photophysiology parameters in coastal or open oceanic stations has often had to be inferred from sparse samplings in various seasons (e.g. Ondrusek et al. 2001, Morán and Estrada 2005) or by modelling from production data and light profiles (Kovać et al. 2016) due to lack of actual measurements. However, mean seasonal cycles can hardly be inferred when only one or a few years are measured, and departures from the average seasonality can definitely not be determined unless a relatively large number of "full seasons" has been described. In the words of Margalef (1969, p. 369), "It is easy to ironically pretend to correctly know the plankton of a site after the study of just one annual cycle. Yet the study needs to continue for many years or even indefinitely if one has the goal of uncovering high level regularities such as interannual patterns". To advance towards that goal, we measured the photosynthetic parameters and estimated phytoplankton primary production and growth rates at approximately monthly intervals for 12 years at a coastal oligotrophic station in the temperate NW Mediterranean Sea in order to describe the seasonality of these patterns and processes, constrain their interannual variability, extract the underlying trends and identify potential drivers, and ultimately set the basis for detecting future changes.

\section{MATERIALS AND METHODS}

\section{Study site}

We established a long-term study at the Blanes Bay Microbial Observatory (BBMO), a well-studied (cf. Gasol et al. 2012) NW Mediterranean shallow (25 m) open bay with a sandy bottom. It is located in front of 
the town of Blanes, between the submarine Blanes Canyon to the north and the mouth of the La Tordera River to the south (see a map and further details in Guadayol et al. 2009). Determinations of gross primary production and net community production by means of the dissolved oxygen method and short-term enrichment bioassays indicated that the bay is net heterotrophic and oligotrophic, with production being limited most of the year by phosphorus (Duarte et al. 2004, Lucea et al. 2005, Pinhassi et al. 2006). A relatively good knowledge of carbon and sulfur cycling has accumulated over the last few years (Alonso-Sáez et al. 2008, Romera-Castillo et al. 2013, Simó et al. 2009). Most terrestrial inputs arrive as runoff from the surrounding coastal area, but there is no direct river input to the site.

Surface waters were sampled for a minimum of once a month at about $800 \mathrm{~m}$ offshore $\left(41^{\circ} 39.9^{\prime} \mathrm{N}, 2^{\circ} 48.3^{\prime} \mathrm{E}\right)$, filtered through a 200-um mesh net, and transported to the lab under dim light (within $1.5 \mathrm{~h}$ ) in 20 -L polycarbonate carboys. Only one surface sample per date was considered for this study. In situ water salinity and temperature were measured with a CTD model SAIV A/S SD204. Secchi disk depth was measured as an integrated estimate of water column turbidity and was used to derive the light diffusion coefficient following the relationship Zsd $\times \mathrm{Kt}=1.7$ (Kirk 1994), where Zsd is the depth of the Secchi disk and Kt is the light diffusion coefficient. Total irradiance was recorded hourly by a pyranometer at the nearby meteorological station of Malgrat de Mar (Catalan Meteorological Service, SMC). In situ irradiance was measured with a spherical downwelling irradiance Li-Cor sensor (Li-193S) and a PAR-UV radiometer (PUV-2500, Biospherical). An index of stratification was estimated as the temperature difference between the surface and values close to the maximal depth $(20 \mathrm{~m})$.

Dissolved inorganic nutrients $\left(\mathrm{NO}_{3}^{-}, \mathrm{NO}_{2}^{-}, \mathrm{NH}_{4}{ }^{+}\right.$, $\mathrm{PO}_{4}{ }^{3-}$ and $\mathrm{SiO}_{2}$ ) were analysed with an Alliance Evolution II autoanalyser following the methods described by Hansen and Koroleff (1999) with minor modifications. Samples were kept frozen at $-20^{\circ} \mathrm{C}$ until analyses. Chlorophyll $a$ (Chl $a$ ) concentration was measured by fluorometry (Turner Designs fluorometer) in $6.5 \mathrm{ml}$ extracts $\left(90 \%\right.$ acetone, $4^{\circ} \mathrm{C}$, overnight) of $150 \mathrm{~mL}$ of seawater filtered through GF/F (Whatman). Parallel filtration onto polycarbonate, 3 - $\mu \mathrm{m}$ pore filters (Poretics) provided the $\mathrm{Chl} a$ concentrations associated with larger organisms.

\section{Phytoplankton abundance and biomass estimation}

Abundance of cyanobacteria (Prochlorococcus spp. and Synechococcus spp.), autotrophic picoeukaryotes and cryptomonads were determined by flow cytometry in a BectonDickinson FACSCalibur instrument following standard methods. Small picoeukaryotes $(\leq 2 \mu \mathrm{m})$ were separated from large picoeukaryotes. Autotrophic nanoplankton were enumerated using epifluorescence microscopy. Abundances were converted to biomass using average $\mathrm{C}$ :cell conversion factors from the literature: $51 \pm 18 \mathrm{fg} \mathrm{C}^{-1 l^{-1}}$ for Prochlorococcus spp., $175 \pm 73 \mathrm{fg} \mathrm{C}$ cell $^{-1}$ for Synechococcus spp., $1319 \pm 813 \mathrm{fg} \mathrm{C}$ cell $^{-1}$ for picoeukaryotes (see

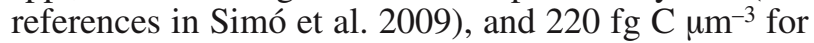
nanophytoplankton (Børsheim and Bratbak 1987). Microphytoplankton were identified and counted with an inverted microscope after sedimentation in Utermöhl chambers. Width and length were measured for each cell and cell volumes were calculated as described in Guadayol et al. (2009). Conversion to $\mathrm{C}$ was done by applying the formula $\mathrm{C}=0.109$ (cell vol.) ${ }^{0.991} \mathrm{fg} \mathrm{C}$ cell $^{-1}$ (Montagnes et al. 1994). For the period March to May 2003 and then after 2004, microphytoplankton biovolume data were not available, and microphytoplankton carbon was estimated from size-fractionated Chl $a$. We observed a good linear relationship $(\mathrm{N}=9$, $\left.\mathrm{R}^{2}=0.88 ; \mathrm{p}<0.05\right)$ between the percentage of total $\mathrm{Chl}$ $a$ in the fraction $>3 \mu \mathrm{m}$ and the percentage of biomass comprised by microphytoplankton plus one-half of the nanophytoplankton and one- fourth of the picoeukaryotes in the months with complete biomass data. Thus, the Chl $a>3 \mu \mathrm{m}$ fraction and the nano- and picophytoplankton biomass values were used to estimate microphytoplankton biomass for the dates on which we had microphytoplankton abundance but not biomass data (see details in Simó et al. 2009).

\section{Photosynthetic parameters}

Monthly from 2003 to 2010 and once per season from 2011 to 2014, samples were retrieved from the surface and used to determine particulate primary production (PPp) using the ${ }^{14} \mathrm{C}$ method (Steeman-Nielsen 1952) from P-E curves. We obtained 114 estimates of ${ }^{14} \mathrm{C}$ incorporation and photosynthetic parameters during this 12 -year period. In total the number of monthly samples ranged from 7 (January, August, December) to 15 (May), with an average of 10.

Thirteen 70-mL bottles (VWR) and one dark control (bottle wrapped with aluminium foil) were filled with seawater and inoculated with $10 \mu \mathrm{Ci} \mathrm{NaH}{ }^{14} \mathrm{CO}_{3}$ (International Agency for ${ }^{14} \mathrm{C}$ Determination, VKI, Denmark). The incubation was carried out in a water bath at in situ temperature for $2 \mathrm{~h}$ in a gradient of artificial PAR (10-1500 umol photons $\mathrm{m}^{-2} \mathrm{~h}^{-1}$ ). Circulating water connected to the water bath maintained the temperature as close as possible to the one measured in situ. Illumination was provided by Phillips halogen lamps $(50 \mathrm{~W})$. The irradiance level at each position was directly measured with an Illuminova AB (Sweden) spherical PAR light-sensor placed inside the bottles. An intercalibration with a spherical Li-Cor quantum sensor proved that both sensors gave similar values (Morán and Estrada 2001). After the incubation, the samples were filtered through $0.2-\mu \mathrm{m}$ pore size cellulose ester Millipore filters (GSWP02500). These filters were put into scintillation vials and left for $24 \mathrm{~h}$ in an $\mathrm{HCl}$ saturated atmosphere. Scintillation cocktail (4 ml, Optiphase Hisafe 2, Perkin Elmer) was then added to each vial, and the radioactivity was measured in a liquid scintillation counter (TriCarb2810, Perkin Elmer). Particulate primary production (PPp) was determined from the P-E curve and the in situ (sampling time) irradiance. 
Chl $a$-normalized PPp measurements were initially fitted to the exponential model of Platt et al. (1980) using nonlinear least-squares regression (KaleidaGraph software):

$$
\mathrm{P}^{\mathrm{B}}=\mathrm{P}^{\mathrm{B}}{ }_{\mathrm{s}}\left[1-\exp \left(-\alpha \mathrm{E} / \mathrm{P}^{\mathrm{B}}{ }_{\mathrm{s}}\right)\right]\left[\exp \left(-\beta \mathrm{E} / \mathrm{P}^{\mathrm{B}}{ }_{\mathrm{s}}\right)\right],
$$

where $\mathrm{P}^{\mathrm{B}}\left[\mathrm{mg} \mathrm{C}(\mathrm{mg} \mathrm{Chl} a)^{-1} \mathrm{~h}^{-1}\right]$ is the Chl $a$-normalized photosynthetic rate, $\mathrm{P}^{\mathrm{B}}{ }_{\mathrm{s}}\left[\mathrm{mg} \mathrm{C}(\mathrm{mg} \mathrm{Chl} a)^{-1}\right.$ $\mathrm{h}^{-1}$ ] is the maximum Chl $a$-normalized photosynthetic rate without photoinhibition, $\alpha\left[\mathrm{mg} \mathrm{C}(\mathrm{mg} \mathrm{Chl} a)^{-1} \mathrm{~h}^{-1}\right.$ ( $\mu \mathrm{mol}$ photons $\left.\mathrm{m}^{-2} \mathrm{~s}^{-1}\right)^{-1}$ ] is the initial slope of the P-E curve and $\beta$ (same units as $\alpha$ ) is the photoinhibition parameter.

As fitted $\beta$ values were 0 in almost all cases, $\mathrm{P}^{\mathrm{B}}{ }_{\mathrm{s}}$ in the model of Platt et al. was equivalent to $\mathrm{P}^{\mathrm{B}}{ }_{\text {max }}$ in the model proposed by Webb et al. (1974):

$$
\mathrm{P}^{\mathrm{B}}=\mathrm{P}_{\text {max }}^{\mathrm{B}}\left[1-\exp \left(-\alpha \mathrm{E} / \mathrm{P}^{\mathrm{B}}{ }_{\mathrm{m}}\right)\right],
$$

where $\mathrm{P}^{\mathrm{B}}{ }_{\text {max }}\left[\mathrm{mg} \mathrm{C}(\mathrm{mg} \mathrm{Chl} a)^{-1} \mathrm{~h}^{-1}\right]$ is the maximum Chl $a$-normalized photosynthetic rate. The saturating irradiance or light saturation parameter $\left(\mathrm{E}_{\mathrm{K}}\right)$ was estimated as $\mathrm{P}_{\text {max }}^{\mathrm{B}} / \alpha$.

In situ light levels and $\mathrm{Chl} a$ concentrations at the sea surface were used to estimate in situ surface primary production at the time of sampling. The values here should be taken as estimates of net particulate phytoplankton primary production since no correction for dark respiration was attempted. There has been some discussion about the use of photosynthetic parameters derived from artificial light sources for estimating in situ primary production, yet the limited number of studies comparing in situ vs P-E-derived carbon fixation rates fail to indicate significant biases with the latter method (see discussion in Morán and Estrada 2005). Daily estimates of total particulate production at the surface were obtained from the monthly average light irradiance in the sampling site, and the monthly-averaged P-E equations and these values were used to estimate average productions for all all the light hours. The integration of these values provided monthly-averaged daily production rates that were then compared with the oxygen-derived gross primary production values measured by $\mathrm{Du}-$ arte et al. (2004) at the same site but for the period 1992-1998.

Phytoplankton ${ }^{14} \mathrm{C}$-derived specific growth rates $\left(\mathrm{GR}, \mathrm{d}^{-1}\right)$ were calculated from primary production (PP) and phytoplankton carbon biomass (PC) assuming exponential growth as $\mathrm{GR}=\ln [1+(\mathrm{PP} / \mathrm{PC})]$. Maximum growth rates $\left(\mathrm{GR}_{\max }\right)$ were estimated from $\mathrm{P}^{\mathrm{B}}{ }_{\max }$ values and $\mathrm{C}: \mathrm{Chl} a$ ratios as $\mathrm{GR}_{\max }=\ln \left[1+\left(\mathrm{P}_{\mathrm{m}}^{\mathrm{B}} / \mathrm{PC}: \mathrm{Chl}\right.\right.$ $a)$. No significant differences were observed when a linear, not a logarithmic, model was assumed for the calculation.

\section{Data analysis strategy and statistical analyses}

We used a basic data analysis strategy in which we averaged all measurements done for each month of the year and we present averages plus standard errors as well as maximum and minimum values for each month. This is the type of data presented in Figures 1 to 6.

In addition, we analysed the variability from season to season, and for this the seasons were defined depending on water temperature and number of hours of light as follows: winter was considered to start when temperatures dropped below $17^{\circ} \mathrm{C}$ and the number of hours of light below $10 \mathrm{~h} \mathrm{~d}^{-1}$. Spring from $12 \mathrm{~h} \mathrm{~d}^{-1}$ of light and temperatures $>13^{\circ} \mathrm{C}$. Summer was considered from temperatures $>18^{\circ} \mathrm{C}$ and more than $15 \mathrm{~h} \mathrm{~d}^{-1}$ of light. When temperatures decreased below $23^{\circ} \mathrm{C}$ (from the maximum of $26^{\circ} \mathrm{C}$ ) and illumination was $<12 \mathrm{~h} \mathrm{~d}^{-1}$, we considered that it was Autumn. These values coincided approximately with the beginning of November (winter), mid-March (spring), the beginning of June (summer) and mid-September (autumn). Differences were tested with one-way ANOVA in JMP software version 9.0 (SAS Institute).

Between-variable Bonferroni-corrected Pearson correlations between untransformed data were produced in SYSTAT (Systat Software Inc, London, UK) after assuring normality and variance homogeneity.
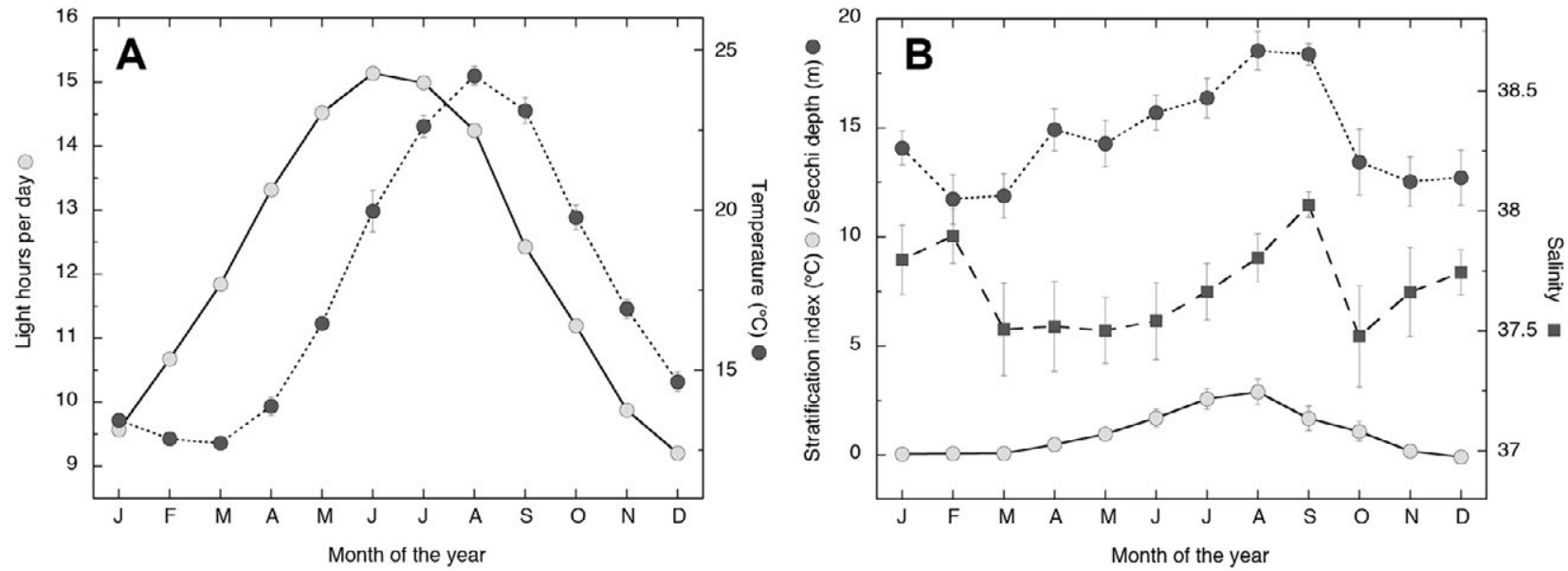

Fig. 1. - A, seasonal evolution in Blanes Bay of the number of light hours per day (grey symbols) and temperature (black symbols); B, seasonal evolution of salinity (black squares), stratification index (temperature difference between surface and bottom, grey circles) and Secchi disk depth (black circles). Monthly averages \pm standard errors. 

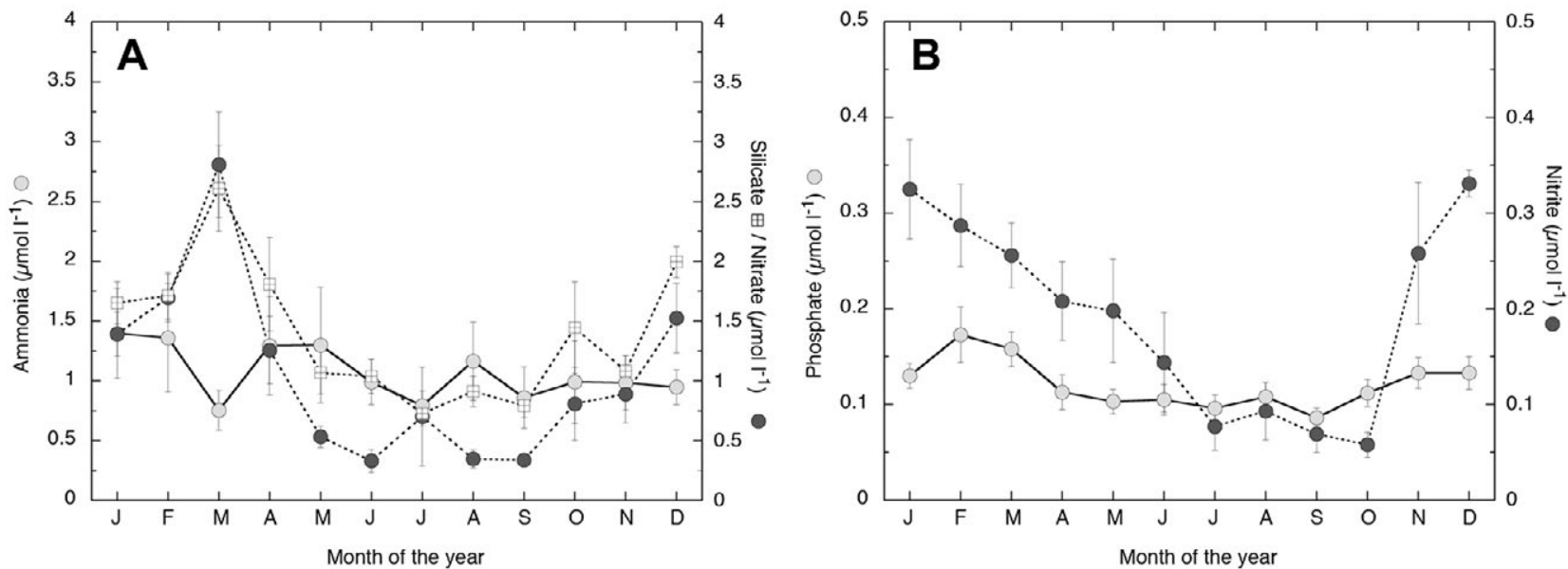

Fig. 2. - Seasonal evolution of average nutrient concentrations in Blanes Bay. A, ammonium (grey circles), nitrate (black symbols) and silicate (squares); B, nitrite (black circles) and phosphate (grey circles). Monthly averages \pm standard errors.
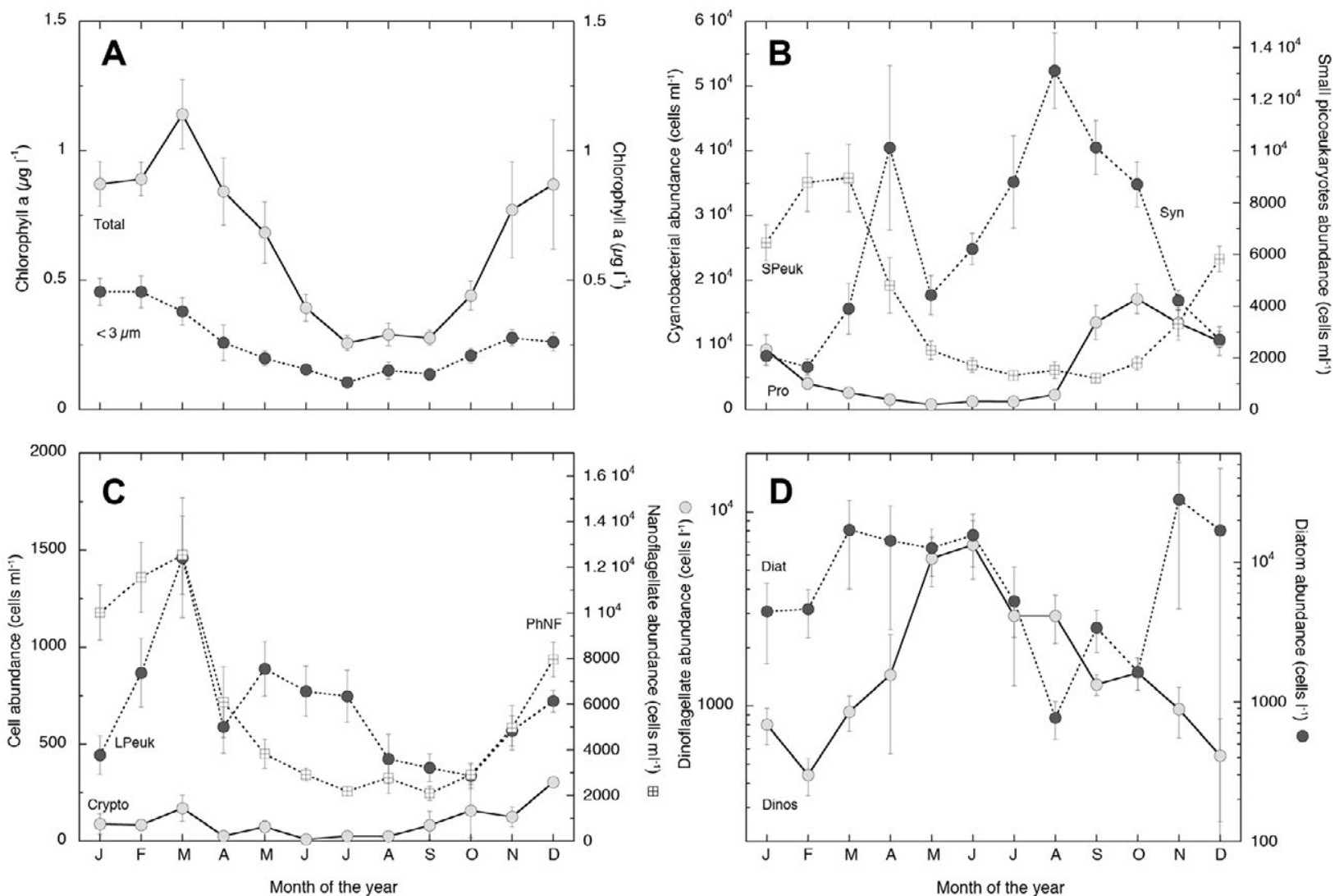

Fig. 3. - Seasonal evolution of phytoplankton in Blanes Bay. A, total chlorophyll $a$ (grey circles) and $<3 \mu$ m chlorophyll $a$ (black symbols); B, Prochlorococcus (grey circles), Synechococcus (black circles) and small picoeukaryote abundance (squares) as determined by flow cytometry; $\mathrm{C}$, large picoeukaryote abundance (black circles) and cryptomonad abundance (grey circles) as determined by flow cytometry and photosynthetic nanoflagellates (squares) determined by epifluorescence microscopy; D, diatoms (black circles) and dinoflagellate (grey circles) abundance determined by inverted microscopy. Monthly averages \pm standard errors.

We used R (R Core Team 2014) and the package vegan (Oksanen et al. 2016) to perform a principal components analysis (PCA) with the independent variables (i.e. photosynthetic parameters, growth and photosynthesis rates) after centering and scaling all variables. The physico-chemical and phytoplankton data were then correlated to the PCA-determined main axes. We also ran simple and partial Mantel tests between three normalized data dissimilarity matrices: the envi- ronmental one (temperature, nutrients, salinity, etc.), the phytoplankton community composition one, and a third one with the independent variables of interest. The Pearson probabilities were determined after 10000 permutations. The partial Mantel tests were used to determine how much the phytoplankton matrix explained the photophysiology and production values after accounting for the environmental effects on both matrices. 
Table 1. - Average values ( \pm standard error of all the measurements), maximal and minimal values observed in the whole sampled period, and results of a one-way ANOVA test (F-ratio and associated P) of the significance of the season. The results of a Tukey-Kramer post-hoc test indicate which of the four seasons are different at P=0.05. W, winter; F, Autumn; S, summer; Sp, spring.

\begin{tabular}{|c|c|c|c|c|c|c|c|c|}
\hline Variable & & $\mathrm{N}$ & $\begin{array}{c}\text { average } \\
\text { SE }\end{array}$ & $\min$ & $\max _{\text {ANOVA F }}$ & Prob & Post-hoc test & \\
\hline Temperature $\left({ }^{\circ} \mathrm{C}\right)$ & 196 & 17.5 & 0.3 & 11.0 & 26.2 & 162.42 & $<0.001$ & $\mathrm{~S}>\mathrm{F}>\mathrm{Sp}>\mathrm{W}$ \\
\hline Stratification Index $\left({ }^{\circ} \mathrm{C}\right)$ & 129 & 1.0 & 0.1 & -1.3 & 6.0 & 16.18 & $<0.001$ & $\mathrm{~S}>\mathrm{F}=\mathrm{Sp}=\mathrm{W}$ \\
\hline Secchi depth (m) & 176 & 14.5 & 0.3 & 3.5 & 24.0 & 8.13 & $<0.001$ & $\mathrm{~S}>\mathrm{F}=\mathrm{Sp}=\mathrm{W}$ \\
\hline Salinity & 172 & 37.66 & 0.05 & 35.08 & 39.09 & 0.54 & 0.31 & \\
\hline Chlorophyll $a\left(\mathrm{mg} \mathrm{m}^{-3}\right)$ & 190 & 0.64 & 0.04 & 0.02 & 3.45 & 11.73 & $<0.001$ & $\mathrm{~W}=\mathrm{Sp}>\mathrm{F}=\mathrm{S}$ \\
\hline$<3 \mu \mathrm{m}$ Chl $a\left(\mathrm{mg} \mathrm{m}^{-3}\right)$ & 167 & 0.24 & 0.01 & 0.00 & 0.89 & 13.71 & $<0.001$ & $\mathrm{~W}>\mathrm{Sp}=\mathrm{F}=\mathrm{S}$ \\
\hline Phosphate concentration $\left(\mu \mathrm{mol} \mathrm{L}{ }^{-1}\right)$ & 194 & 0.12 & 0.01 & 0.02 & 0.47 & 6.55 & 0.009 & $\mathrm{~W}=\mathrm{Sp}=\mathrm{F}>\mathrm{S}$ \\
\hline Ammonium concentration $(\mu \mathrm{mol} \mathrm{L}-1)$ & 194 & 1.06 & 0.09 & 0.03 & 7.40 & 1.25 & 0.66 & \\
\hline Nitrite concentration $\left(\mu \mathrm{mol} \mathrm{L}{ }^{-1}\right)$ & 194 & 0.19 & 0.02 & 0.00 & 1.28 & 4.31 & $<0.001$ & $\mathrm{~W}>\mathrm{Sp}=\mathrm{F}>\mathrm{S}$ \\
\hline Nitrate concentration $\left(\mu \mathrm{mol} \mathrm{L}^{-1}\right)$ & 194 & 1.08 & 0.09 & 0.00 & 7.29 & 14.52 & $<0.001$ & $\mathrm{~W}>\mathrm{Sp}=\mathrm{F}=\mathrm{S}$ \\
\hline Silicate concentration $(\mu \mathrm{mol} \mathrm{L}-1)$ & 194 & 1.42 & 0.08 & 0.04 & 7.59 & 6.81 & $<0.001$ & $\mathrm{~W}=\mathrm{Sp}=\mathrm{F}>\mathrm{S}$ \\
\hline Phot. Nanoflagellates (cells ml-1) & 161 & 5822 & 450 & 776 & 41247 & 16.43 & $<0.001$ & $\mathrm{~W}>\mathrm{Sp}=\mathrm{F}>\mathrm{S}$ \\
\hline Cryptomonads (cells $\mathrm{ml}^{-1}$ ) & 161 & 146 & 18 & 0 & 2272 & 3.18 & 0.03 & \\
\hline Prochlorococcus (cells ml ${ }^{-1}$ ) & 189 & 6594 & 595 & 0 & 39448 & 18.35 & $<0.001$ & $\mathrm{~F}>\mathrm{W}>\mathrm{S}=\mathrm{Sp}$ \\
\hline Synechococcus (cells ml-1) & 189 & 25177 & 1673 & 672 & 149706 & 11.77 & $<0.001$ & $\mathrm{~S}=\mathrm{F}>\mathrm{Sp}>\mathrm{W}$ \\
\hline Small picoeukaryotes (cells $\mathrm{ml}^{-1}$ ) & 189 & 4003 & 318 & 307 & 27745 & 19.20 & $<0.001$ & $\mathrm{~W}>\mathrm{Sp}>\mathrm{F}=\mathrm{S}$ \\
\hline Large picoeukaryotes (cells ml-1) & 189 & 698 & 51 & 0 & 5826 & 4.93 & 0.005 & $\mathrm{Sp}=\mathrm{W}>\mathrm{S}=\mathrm{F}$ \\
\hline Dinoflagellates (cells $\left.1^{-1}\right)$ & 118 & 2416 & 359 & 100 & 27330 & 5.48 & 0.002 & $\mathrm{Sp}=\mathrm{S}=\mathrm{F}>\mathrm{W}$ \\
\hline Diatoms (cells $\left.1^{-1}\right)$ & 118 & 10532 & 2379 & 20 & 215622 & 0.56 & 0.36 & \\
\hline $\mathrm{P}_{\max }^{\mathrm{B}}\left(\mathrm{mg} \mathrm{C} \mathrm{mg} \mathrm{Chl} a^{-1} \mathrm{~h}^{-1}\right)$ & 114 & 3.72 & 0.25 & 0.49 & 14.81 & 5.17 & $<0.001$ & $\mathrm{~S}>\mathrm{F}=\mathrm{W}=\mathrm{Sp}$ \\
\hline$\alpha^{\mathrm{B}}\left(\mathrm{mg} \mathrm{C} \mathrm{mg} \mathrm{Chl} a^{-1} \mathrm{~h}^{-1}\left(\mu \mathrm{mol} \text { phot } \mathrm{m}^{-2} \mathrm{~s}^{-1}\right)^{-1}\right)$ & 114 & 0.007 & 0.001 & 0.001 & 0.045 & 0.89 & 0.31 & \\
\hline $\mathrm{E}_{\mathrm{k}}\left(\mu \mathrm{mol}\right.$ phot $\left.\mathrm{m}^{-2} \mathrm{~s}^{-1}\right)$ & 114 & 711.5 & 58.4 & 86.3 & 4566.7 & 1.65 & 0.11 & \\
\hline Primary production $\left(\mathrm{mg} \mathrm{C} \mathrm{m}^{-3} \mathrm{~h}^{-1}\right)$ & 114 & 1.45 & 0.13 & 0.07 & 7.34 & 3.42 & 0.002 & $\mathrm{~W}=\mathrm{Sp}>\mathrm{S}=\mathrm{F}$ \\
\hline Specific primary prod. (mg C mg Chl $\left.a^{-1} \mathrm{~h}^{-1}\right)$ & 114 & 2.49 & 0.19 & 0.05 & 12.63 & 3.14 & 0.002 & $\mathrm{~S}=\mathrm{F}>\mathrm{W}=\mathrm{Sp}$ \\
\hline Total phytoplankton $\mathrm{C}\left(\mu \mathrm{g} \mathrm{C} 1^{-1}\right)$ & 103 & 37.59 & 3.36 & 10.81 & 203.54 & 6.58 & 0.004 & $\mathrm{~W}=\mathrm{Sp}>\mathrm{F}=\mathrm{S}$ \\
\hline Ratio C:Chl & 100 & 65.2 & 3.73 & 13.9 & 253.3 & 4.39 & 0.006 & $\mathrm{~S}>\mathrm{Sp}=\mathrm{W}=\mathrm{F}$ \\
\hline$\%$ picophytoplankton & 103 & 33.3 & 1.6 & 3.8 & 74.8 & 5.08 & 0.003 & $\mathrm{~S}=\mathrm{F}>\mathrm{W}=\mathrm{Sp}$ \\
\hline$\%$ nanophytoplankton & 103 & 31.5 & 1.6 & 3.8 & 78.9 & 1.73 & 0.16 & \\
\hline$\%$ microphytoplankton & 103 & 35.2 & 2.1 & 4.4 & 88.7 & 0.63 & 0.59 & \\
\hline Growth rate $\left(\mathrm{d}^{-1}\right)$ & 102 & 0.42 & 0.03 & 0.03 & 1.28 & 1.15 & 0.33 & \\
\hline Maximal growth rate $\left(\mathrm{d}^{-1}\right)$ & 101 & 0.55 & 0.03 & 0.07 & 1.40 & 0.92 & 0.44 & \\
\hline $\mathrm{GR}_{\max } / \mathrm{GR}$ & 101 & 1.69 & 0.19 & 0.34 & 15.43 & 0.98 & 0.41 & \\
\hline
\end{tabular}

\section{RESULTS}

\section{Characterization of the seasonality of the site}

The Blanes Bay Microbial Observatory is a shallow site (max. $25 \mathrm{~m}$ depth) close to the coast $(800$ $\mathrm{m})$ and relatively unaffected by river discharges and human impacts (Guadayol et al. 2009) that we have identified as a reference for coastal oligotrophic sta-

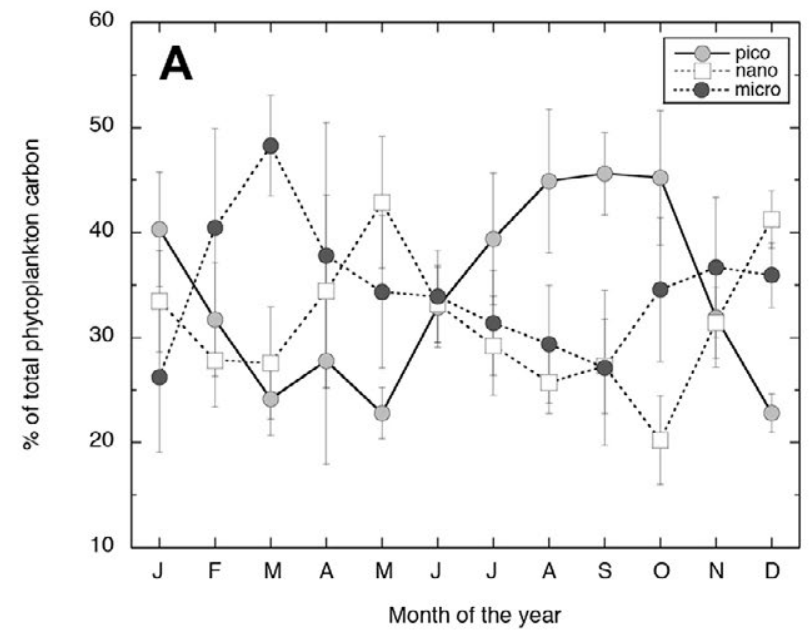

tions. The seasonal cycle of oceanographic variables is typical for a temperate coastal system. June and July showed the highest number of light hours (ca. $15 \mathrm{~h}$ ) and December and January the lowest (ca. $9 \mathrm{~h}$ ), and this resulted in temperature (Fig. 1A) varying from a minimum of $12^{\circ} \mathrm{C}$ (February/March) to a maximum of $24^{\circ} \mathrm{C}$ (August). The site was therefore stratified in summer (April-October) and well mixed between November and March (Fig. 1B). Salinity varied from a

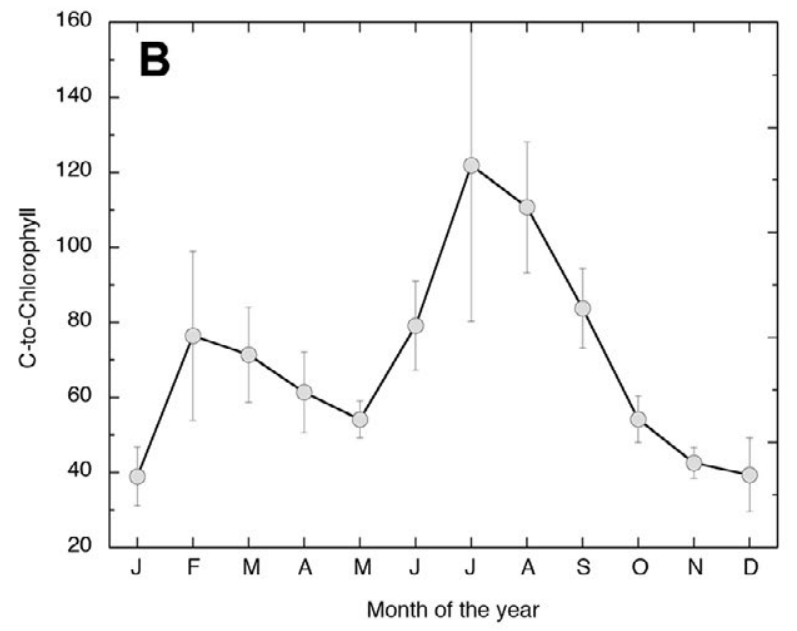

Fig. 4. - Seasonal evolution of the average estimated phytoplankton carbon and relation to chlorophyll in Blanes Bay. A, estimated phytoplankton carbon contributed by picophytoplankton (grey circles), nanophytoplankton (squares) and microphytoplankton (black symbols); B, carbon-to-chlorophyll estimates. Monthly averages \pm standard errors. 
minimum of 37.5 in March to a maximum of 38.0 in September (Fig. 1B).

Inorganic nutrients had maximum concentrations in winter and were lower from May to September/October (Fig. 2). Nitrate and silicate were below $1 \mu \mathrm{mol} \mathrm{L}-1$ in summer and reached $3 \mu \mathrm{mol} \mathrm{L^{-1 }}$ on average in March (Fig. 2A). Ammonia remained at $1 \mu \mathrm{mol} \mathrm{L} \mathrm{L}^{-1}$ in summer and increased slightly in the spring. Concentrations of phosphate and nitrite in summer were near $0.1 \mu \mathrm{mol} \mathrm{L} \mathrm{L}^{-1}$ and increased to $0.2-0.4 \mu \mathrm{mol} \mathrm{L} \mathrm{L}^{-1}$ in winter (Fig. 2B).

Average (SE) Chl $a$ concentration was $0.64 \mu \mathrm{g} \mathrm{L} \mathrm{L}^{-1}$ $( \pm 0.04)$ (Table 1$)$, with winter values around $1 \mu \mathrm{g} \mathrm{L}^{-1}$ (Fig. 3A) and summer values of $0.3 \mu \mathrm{g} \mathrm{L}^{-1}$. The fraction of Chl $a<3 \mu \mathrm{m}$ varied from $c a$. $0.2 \mu \mathrm{g} \mathrm{L}^{-1}$ in summer to $0.5 \mu \mathrm{g} \mathrm{L}^{-1}$ in winter, and was a larger fraction of total Chl $a$ in summer. There was a marked seasonality of the various components of the picophytoplankton, with larger abundances of small (Fig. 3B) and large (Fig. 3C) picoeukaryotes in December-March, of Synechococcus between April and October, and of Prochlorococcus between September and December (Fig. 3B), yet the latter were never very abundant. Plastidic nanoflagellates enumerated by epifluorescence microscopy followed a very marked seasonality almost parallel to that of total Chl $a$ (Fig. 3C). Finally, among the microphytoplankton, dinoflagellates were more abundant in early summer (May-August, Fig. 3D) and diatoms from mid-autumn to late spring (Fig. 3D). In terms of contribution to photosynthetic biomass (Fig. 4A), microphytoplankton dominated in late winter/early spring, picophytoplankton from July to October, and nanophytoplankton in late spring/early summer and then again in early winter. The ratio of carbon biomass to Chl $a$ revealed a very clear seasonal cycle (Fig. 4B), with low $\mathrm{C}$ : Chl $a$ values in autumn and early winter $(<50)$, and values $>100$ from June to September.

\section{Phytoplankton photosynthetic parameters, production and growth}

We obtained 114 estimates of ${ }^{14} \mathrm{C}$ incorporation and photosynthetic parameters during a 12-year period, from March 2003 to November 2014. While during the first 8 years we sampled at monthly intervals, we decreased the frequency after 2010 to every 3 months. Photoinhibition was observed only twice during this period, in May 2003 and in February 2012, with $\beta$ values of 0.001 and $0.046 \mathrm{mg} \mathrm{C} \mathrm{mg} \mathrm{Chl} a^{-1} \mathrm{~h}^{-1}$ ( $\mu$ mol photons $\left.\mathrm{m}^{-2} \mathrm{~s}^{-1}\right)^{-1}$ respectively. The maximal photosynthetic rate $\mathrm{P}^{\mathrm{B}}{ }_{\max }$ ranged one order of magnitude (0.5-15.0 mg C mg Chl $a^{-1} \mathrm{~h}^{-1}$, Table 1, Fig. 5A), and reached the maximum values in August and the minimum values in April and December. The initial or light-limited slope of the P-E relationship, $\alpha^{\mathrm{B}}$, averaged $0.007\left( \pm 0.001\right.$, range 0.001-0.045) mg C mg Chl $a^{-1} \mathrm{~h}^{-1}$ ( $\mu$ mol photons $\left.\mathrm{m}^{-2} \mathrm{~s}^{-1}\right)^{-1}$ but was rather stable seasonally, with somewhat lower values in spring (Fig 5A). The light saturation parameter or saturation irradiance, $\mathrm{E}_{\mathrm{K}}$, averaged $712 \pm 58 \mu \mathrm{mol}$ photons $\mathrm{m}^{-2} \mathrm{~s}^{-1}$ and tended to be higher in the months with higher total irradiance (Fig. 5B). We compared the value of $\mathrm{E}_{\mathrm{K}}$ with the radiation measured at the water surface and at $5 \mathrm{~m}$ depth.
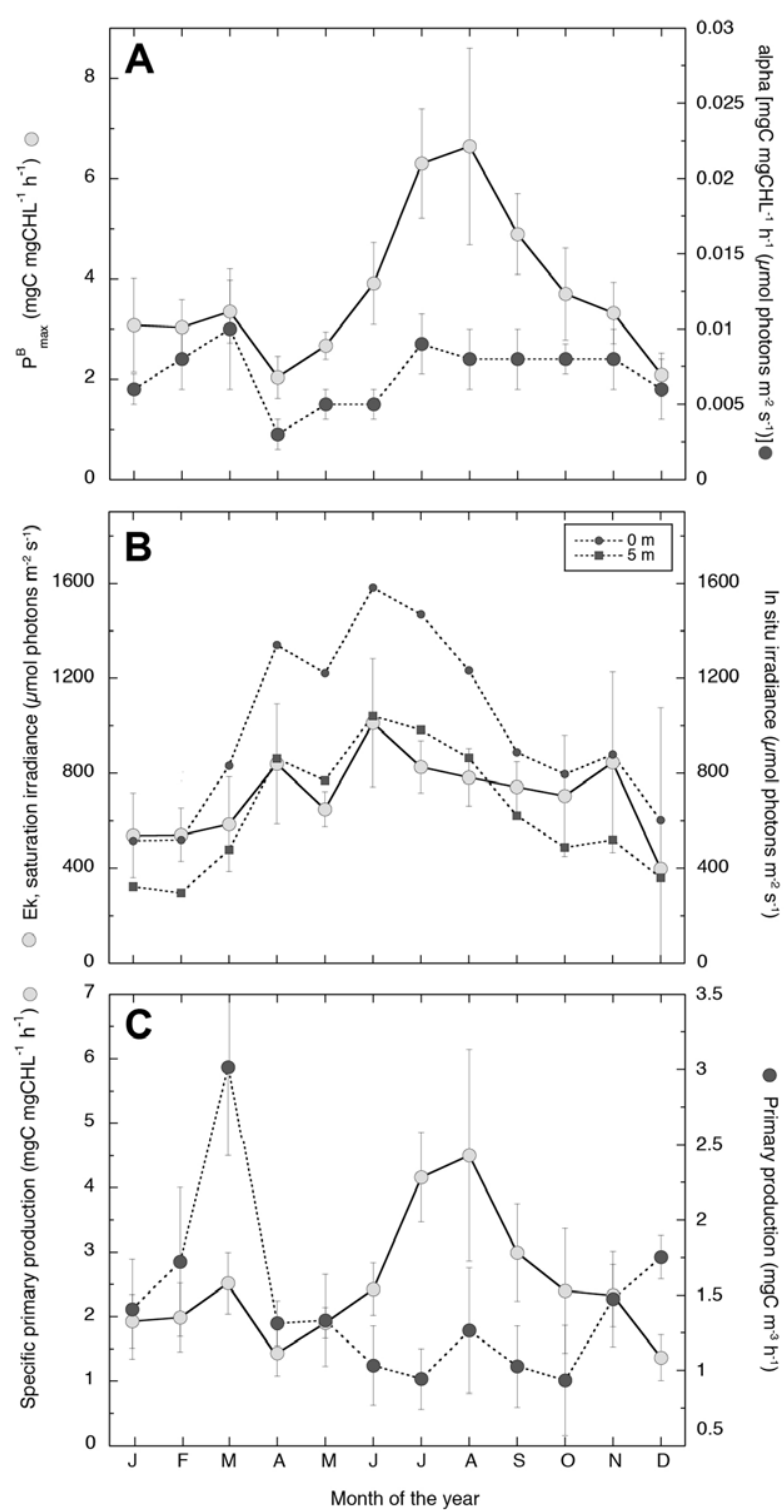

Fig. 5. - Seasonal evolution of the average values of the photosynthetic parameters and primary production in Blanes Bay. A, maximum photosynthetic rate, $\mathrm{P}^{\mathrm{B}}{ }_{\max }$ (grey circles) and initial or light-limited slope of the P-E relationship $\alpha^{\mathrm{B}}$ (black symbols); $\mathrm{B}$, the average light saturation parameter or saturation irradiance, $E_{\mathrm{k}}$ (grey circles), and in situ irradiance at the time of sampling at the surface and at $5 \mathrm{~m}$ depth; $\mathrm{C}$, hourly primary production (black circles) and chlorophyll-specific primary production (grey circles). Monthly averages \pm standard errors.

In winter, the observed values of $E_{K}$ were close to the surface irradiance at the time of sampling. In summer, they were close to the irradiance values observed at 5 $m$ depth. In all cases, the observed $E_{K}$ were within the values delimited by the surface irradiance and that at 5 $\mathrm{m}$ depth.

Using the in situ irradiance and the measured photosynthetic parameters, we estimated in situ primary production (Fig. 5C). The hourly primary production rates varied between 0.07 and $7.34 \mathrm{mg} \mathrm{C} \mathrm{L}^{-1} \mathrm{~h}^{-1}$, with an average value of $1.45 \pm 0.13$. Primary production was higher in winter (Table 1), particularly in March, and lower in the summer months. Conversely, chlorophyllspecific primary production varied 200 -fold between 


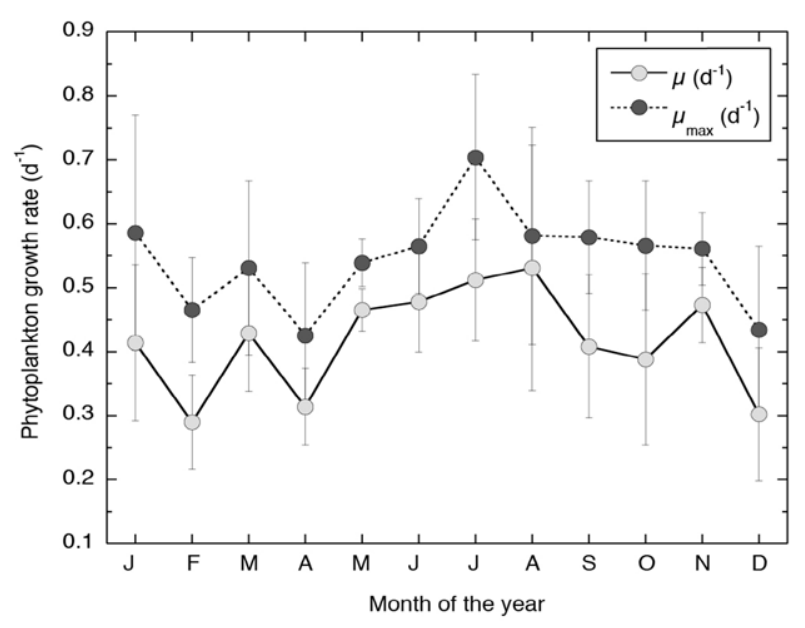

Fig. 6. - Seasonal evolution of the average estimated phytoplankton growth rates in Blanes Bay. Phytoplankton growth rate (grey circles) and maximum growth rate (black circles). Monthly averages \pm standard errors.

0.05 and $12.6 \mathrm{mg} \mathrm{C} \mathrm{mg} \mathrm{Chl} a^{-1} \mathrm{~h}^{-1}$ (Table 1), with an average value of $2.49 \pm 0.19$. Chlorophyll-specific primary production was higher in summer (average for July and August, $4.5 \mathrm{mg} \mathrm{C} \mathrm{mg} \mathrm{Chl} a^{-1} \mathrm{~h}^{-1}$ ) and lowest in winter (1.2 in December, Table 1).

With the estimated total phytoplankton carbon, we computed actual (i.e. at the in situ irradiance) and maximal (based on $\mathrm{P}_{\text {max }}^{\mathrm{B}}$ ) phytoplankton growth rates (Fig 6). With an average of ca. 0.4-0.5 d $\mathrm{d}^{-1}$, the growth rates showed little seasonality (Fig. 6 and Table 1), with phytoplankton growing slightly faster in summer

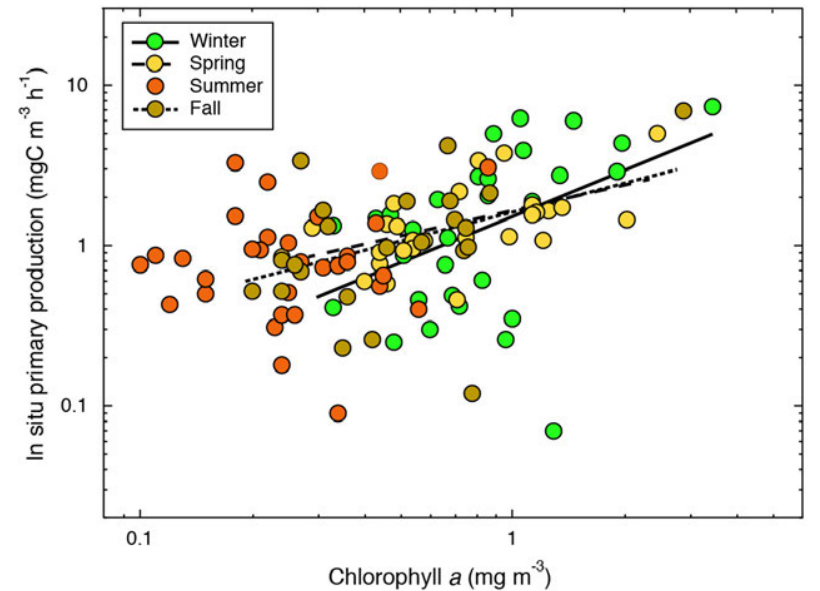

Fig. 7. - Log-log relationships between total chlorophyll $a$ (Chl a) and in situ hourly primary production (PP) in winter (green symbols), spring (orange symbols), summer (red symbols) and autumn (brown symbols). The log-log regression equations are as follows: winter, $\log \mathrm{PP}=0.11+0.95 \times \log \mathrm{Chl} a(\mathrm{~N}=30, \mathrm{P}<0.05)$; spring, $\log \mathrm{PP}=0.20+0.58 \times \log C h \mathrm{l} a(\mathrm{~N}=28, \mathrm{P}<0.05)$; summer, $\log \mathrm{PP}=-0.01+0.18 \times \log C h l a(\mathrm{~N}=32$, not significant $)$; autumn, $\log \mathrm{PP}=0.21+0.64 \times \log \mathrm{Chl} a(\mathrm{~N}=23, \mathrm{P}<0.05)$.

$\left(\sim 0.5 \mathrm{~d}^{-1}\right)$ than in winter $\left(\sim 0.35 \mathrm{~d}^{-1}\right)$. Maximum growth rates were on average 1.4 -fold the in situ rates of phytoplankton growth.

With all data pooled, primary production was significantly related to chlorophyll $(\mathrm{N}=113$, Pearson $\mathrm{R}=0.67, \mathrm{P}<0.007$ ), but the ordinary least square slope between these two variables was low (log-log slope of PPp as a function of Chl $a, 0.53 \pm 0.11, \mathrm{P}<0.001$,

Table 2. - Pearson correlations with Bonferroni-corrected probabilities for primary production, phytoplankton growth and photosynthetic

\begin{tabular}{|c|c|c|c|c|}
\hline Variable & Explanatory variable & $\mathrm{N}$ & correlation & Prob \\
\hline $\mathrm{P}_{\text {max }}^{\mathrm{B}}$ & $\begin{array}{l}\text { Temperature } \\
\text { Stratification Index } \\
\text { Specific production } \\
\text { Synechococcus abundance } \\
\text { C to chlorophyll ratio } \\
\text { Growth rate } \\
\text { Maximal growth rate }\end{array}$ & $\begin{array}{l}114 \\
80 \\
114 \\
110 \\
101 \\
102 \\
101\end{array}$ & $\begin{array}{l}0.429 \\
0.581 \\
0.825 \\
0.360 \\
0.391 \\
0.573 \\
0.658\end{array}$ & $\begin{array}{c}0.001 \\
<0.0001 \\
<0.0001 \\
0.062 \\
0.03 \\
<0.0001 \\
<0.0001\end{array}$ \\
\hline$\alpha^{\mathrm{B}}$ & $\begin{array}{l}\text { Diatom abundance } \\
\text { Particulate Production }\end{array}$ & $\begin{array}{c}67 \\
114\end{array}$ & $\begin{array}{l}0.650 \\
0.362\end{array}$ & $\begin{array}{c}<0.0001 \\
0.042\end{array}$ \\
\hline $\mathrm{E}_{\mathrm{k}}$ & Maximal growth rate & 101 & 0.376 & 0.059 \\
\hline Specific Production & $\begin{array}{l}\text { Temperature } \\
\text { Stratification Index } \\
\text { Light } \\
\mathrm{P}^{\mathrm{B}}{ }_{\max } \\
\text { Particulate Production } \\
\text { Growth rate } \\
\text { Maximal growth rate }\end{array}$ & $\begin{array}{c}114 \\
80 \\
70 \\
114 \\
114 \\
102 \\
101\end{array}$ & $\begin{array}{l}0.372 \\
0.608 \\
0.453 \\
0.825 \\
0.407 \\
0.746 \\
0.488\end{array}$ & $\begin{array}{c}0.026 \\
<0.0001 \\
0.047 \\
<0.0001 \\
0.004 \\
<0.0001 \\
<0.0001\end{array}$ \\
\hline Particulate Production & $\begin{array}{l}\text { Chlorophyll } a \\
\text { Chl<3 } \\
\alpha^{\mathrm{B}} \\
\text { Specific Production } \\
\text { Photosynthetic nanoflagellates } \\
\text { Cryptomonads } \\
\text { Small picoeukaryotes } \\
\text { Growth rate }\end{array}$ & $\begin{array}{l}113 \\
105 \\
114 \\
114 \\
110 \\
110 \\
110 \\
102\end{array}$ & $\begin{array}{l}0.674 \\
0.378 \\
0.362 \\
0.407 \\
0.479 \\
0.538 \\
0.476 \\
0.493\end{array}$ & $\begin{array}{c}<0.0001 \\
0.004 \\
0.042 \\
0.004 \\
<0.0001 \\
<0.0001 \\
<0.0001 \\
<0.0001\end{array}$ \\
\hline Growth Rate & $\begin{array}{l}\text { Light } \\
\mathrm{P}^{\mathrm{B}}{ }_{\max } \\
\text { Specific Production } \\
\text { Particulate Production } \\
\text { Maximal growth rate }\end{array}$ & $\begin{array}{c}64 \\
102 \\
102 \\
102 \\
101\end{array}$ & $\begin{array}{l}0.502 \\
0.573 \\
0.746 \\
0.493 \\
0.731\end{array}$ & $\begin{aligned} & 0.013 \\
< & 0.0001 \\
< & 0.0001 \\
< & 0.0001 \\
< & 0.0001\end{aligned}$ \\
\hline
\end{tabular}


Table 3. - Results of the principal component analyses (PCA). A, the three main components with the variance explained and the loading of the different photosynthesis parameters on each component; B, correlation between the variables and the two principal components identified in $\mathrm{A} . \mathrm{N}=114$. $* \mathrm{P}<0.05 ; * * \mathrm{P}<0.01$.

\begin{tabular}{lccc}
\hline A) Parameters & PC1 $(42.1 \%)$ & PC2 $(22.0 \%)$ & PC3 (13.1\%) \\
\hline $\mathrm{P}^{\mathrm{B}}{ }_{\text {max }}$ & 1.59 & -0.53 & 0.11 \\
$\alpha^{\mathrm{B}}$ & 0.24 & 0.94 & -1.42 \\
Specific production & 1.68 & 0.13 & 0.38 \\
Production & 1.04 & 0.93 & -0.60 \\
$\mathrm{E}_{\mathrm{k}}$ & 0.43 & -1.39 & -0.23 \\
Growth rate & 1.69 & 0.27 & 0.20 \\
Maximal growth rate & 1.47 & -0.69 & -0.35 \\
$\mathrm{GR}{ }_{\text {max }} / \mathrm{GR}$ & -0.49 & -1.30 & -0.98 \\
\hline $\mathrm{B})$ Correlation to: & $\mathrm{PC} 1$ & $\mathrm{PC} 2$ & \\
\hline Temperature & $0.25^{*}$ & -0.17 & \\
Stratification Index & $0.50^{* *}$ & -0.02 & \\
Secchi depth & 0.05 & -0.17 & \\
Chlorophyll $a$ & -0.06 & $0.40^{* *}$ & \\
Phosphate conc. & $-0.31 *$ & 0.15 & \\
Ammonia conc. & 0.13 & -0.06 & \\
Nitrite conc. & -0.01 & 0.02 & \\
Nitrate conc. & -0.17 & 0.15 & \\
Silicate conc. & $-0.29 *$ & 0.17 & \\
Dinoflagellates & -0.09 & 0.10 & \\
Diatoms & -0.02 & $0.48^{* *}$ & \\
Phot. Nanoflagellates & -0.09 & 0.16 & \\
Cryptomonads & -0.04 & $0.26^{*}$ & \\
Prochlorococcus & -0.07 & -0.02 & \\
Synechococcus & 0.09 & -0.07 & \\
Small picoeukaryotes & -0.12 & $0.24^{*}$ & \\
Large picoeukaryotes & -0.04 & $0.26^{*}$ & \\
\hline
\end{tabular}

$\mathrm{N}=113$ ) as compared with previous global estimates (de Lafontaine and Peters 1986; Baines et al. 1994). Interestingly, the relationship changed (Fig. 7) from having a higher slope in winter $(\mathrm{N}=30, \log -\log$ slope: $\left.0.95 \pm 0.36, \mathrm{r}^{2}=0.47, \mathrm{P}=0.01\right)$ to having a lower one in spring $\left(\mathrm{N}=28\right.$, slope: $\left.0.59 \pm 0.15, \mathrm{r}^{2}=0.53, \mathrm{P}<0.01\right)$ and in the autumn $\left(\mathrm{N}=23\right.$, slope: $0.64 \pm 0.31, \mathrm{r}^{2}=0.37$, $\mathrm{P}=0.04)$, and a non-significant value in summer $(\mathrm{N}=32$, $\mathrm{P}=0.54)$. Production values in summer were above the general trend (i.e. more production per unit of chlorophyll), and this generated the observed seasonality in chlorophyll-specific production (Fig. 5C).

\section{Factors determining primary production, photosynthetic parameters and phytoplankton growth}

Given the strong seasonal component, with parallel changes in temperature, stratification, light penetration, nutrient levels and phytoplankton, it is no surprise that the parameters of the photosynthesis-irradiance model were correlated in some way or another to seasonallyvarying variables. $\mathrm{P}^{\mathrm{B}}{ }_{\text {max }}$, for example, was positively related to variables increasing in summer (i.e. temperature, stratification and less strongly Synechococcus abundance, Table 2). The initial slope of the P-E curve $\left(\alpha^{\mathrm{B}}\right)$ was positively related to particulate production, and strongly related to diatom abundance (Pearson's $\mathrm{r}=0.65$, Table 2). The saturation irradiance $\mathrm{E}_{\mathrm{k}}$ was only weakly correlated with phytoplankton maximum growth rate.

Total particulate production was positively correlated with $\mathrm{Chl} a(\mathrm{r}=0.67)$ and with the abundance of phytoplankton groups developing in wintertime, such as picoeukaryotes, cryptomonads and photosynthetic
Table 4. - Results of the full and partial Mantel analyses based on Pearson's product-moment correlation. The statistic is tested after 10000 permutations. The physico-chemical (PCm) matrix includes temperature, salinity, nutrients, stratification index and in situ light. The phytoplankton matrix (PHYm) includes organism abundance from flow cytometry, inverted microscopy and epifluorescence microscopy data. The photosynthetic parameters matrix (PHOm) includes the photophysiology parameters, production, and phytoplankton growth rates.

\begin{tabular}{lccc}
\hline \multicolumn{1}{c}{ Variables } & Mantel statistic & Prob. \\
\hline Full & PCm vs. PHYm & 0.430 & $<0.001$ \\
& PCm vs. PHOm & 0.183 & 0.013 \\
PHYm vs. PHOm & 0.099 & 0.092 \\
Partial Mantel, PHOm fixed & & \\
$\quad$ PCm vs. PHYm & 0.421 & $<0.001$ \\
Partial Mantel, PHYm fixed & & 0.023 \\
PCm vs. PHOm & 0.156 & 0.322 \\
\hline $\begin{array}{l}\text { Partial Mantel, PCm fixed } \\
\text { PHYm vs. PHOm }\end{array}$ & 0.023 & \\
\hline
\end{tabular}

flagellates (all $\mathrm{r}$ values $>0.45$, Table 2 ). In contrast, Chl $a$-specific production was correlated with the "summer" variables, i.e. temperature, stratification and light, and strongly with $\mathrm{P}^{\mathrm{B}}{ }_{\max }(\mathrm{r}=0.83)$. Phytoplankton growth rates were also correlated with in situ light, albeit not strongly, and with $\mathrm{P}_{\text {max }}^{\mathrm{B}}$, total and specific production.

A principal component analysis of the determined photophysiology and production variables identified two main axes that together explained $64 \%$ of the variance (axis 1, 42\%; axis 2, 22\%, Table 3). The first axis was determined by specific production, $\mathrm{E}_{\mathrm{K}}, \mathrm{P}^{\mathrm{B}}{ }_{\max }$ and growth rate, while the second axis was determined by $\alpha^{\mathrm{B}}$ and $\mathrm{E}_{\mathrm{K}}$. Correlation of the physical and biological variables with these two factors identified the first axis as contributed by stratification and temperature (positively) and silicate and phosphate (negatively), clearly indicating the physically-enforced seasonality. The second axis was related to phytoplankton composition, with positive loadings of $\mathrm{Chl} a$, diatoms, picoeukaryotes and photosynthetic nanoflagellates. To further test the role of community composition in determining the photophysiology parameters and the rates of primary production, we constructed three similarity matrices, one with the environmental data alone (PCm), one with the parameters (PHOm), and one with the phytoplankton composition data (PHYm). Partial Mantel correlation tests between the three matrices indicated that phytoplankton community composition and the photophysiology parameters were related to the environmental data (Mantel $\mathrm{r}=0.42, \mathrm{P}<0.001$, and $\mathrm{r}=0.16, \mathrm{P}=0.02$ respectively, Table 4 ), while these two matrices were not significantly correlated. These two analyses support the minor role of phytoplankton community composition in primary production and variability of photophysiology parameters.

Finally, we calculated trends in annual anomalies in the parameters of interest using the approach of Mackas et al. (2001), as explained in O'Brien (2012), to remove the seasonal signal from the annual calculations. None of the regressions between annual anomalies and year (from 2003 to 2010, when we had estimates for all months) were significant for the photosynthesis and production variables, except for $\mathrm{E}_{\mathrm{K}}$, which showed an increasing trend with time $(\mathrm{N}=8$, $\mathrm{F}=7.4, \mathrm{P}=0.034)$. 


\section{DISCUSSION}

\section{Seasonality of the photosynthetic parameters}

The maximal photosynthetic rates measured in Blanes Bay $\left(\mathrm{P}^{\mathrm{B}}{ }_{\max }, 0.5-15 \mathrm{mg} \mathrm{C} \mathrm{mg} \mathrm{Chl} a^{-1} \mathrm{~h}^{-1}\right)$ were within values measured in other seasonal studies, i.e. 0.1-17.4 for pico- and total phytoplankton in the Bay of Biscay (Morán 2007, Morán and Scharek 2015), 0.89.9 in the Wadden Sea (Tillmann et al. 2000), 1-11 in the Black Sea (Finenko et al. 2002) and 0.1-21.2 mg $\mathrm{C} \mathrm{mg} \mathrm{Chl} a^{-1} \mathrm{~h}^{-1}$ in the Rhode river estuary (Gallegos 2012), and within values previously measured in the western Mediterranean Sea (0.6-5, Morán and Estrada 2001) and the Atlantic Ocean (0.3-14, Marañón and Holligan 1999). $\mathrm{P}^{\mathrm{B}}{ }_{\max }$ varied through our data set about the same magnitude as $\mathrm{Chl} a$ (coefficient of variation, CV: 6.8 vs $7.9 \%$ ). The variation observed at the surface in an Atlantic Ocean transect by Marañón and Holligan (1999) was about one order of magnitude lower. Our measured variability in surface waters was of a similar magnitude to that observed throughout the Atlantic and at various depths.

Temperature has been shown to explain a large percentage of the value of $\mathrm{P}^{\mathrm{B}}{ }_{\max }$ in various environments (e.g. Tillmann et al. 2000). Yet, it is commonly assumed that $\mathrm{P}^{\mathrm{B}}{ }_{\max }$ is higher when there is no nutrient limitation. Our summer values for Blanes Bay were larger than winter ones (Fig. 5A), and were thus contrary to the distributions of nutrients (Fig. 2). $\mathrm{P}_{\text {max }}^{\mathrm{B}}$ was statistically significantly related to phytoplankton growth rates and to chlorophyll-specific production, as expected from the way in which it is calculated. Only the abundance of Synechococcus was somehow correlated with $\mathrm{P}^{\mathrm{B}}{ }_{\max }$, but this was probably due to covariation with temperature and stratification.

The values we measured of $\alpha^{\mathrm{B}}$, the initial slope of the P-E curve, varied more than $\mathrm{P}^{\mathrm{B}}{ }_{\max }(\mathrm{CV}: 29 \%)$ (range 0.001-0.045 $\mathrm{mg} \mathrm{C} \mathrm{mg} \mathrm{Chl} a^{-1} \mathrm{~h}^{-1}$ ( $\mu$ mol phot $\left.\left.\mathrm{m}^{-2} \mathrm{~s}^{-1}\right)^{-1}\right)$. They were lower than those measured in the Wadden Sea (0.02, Tillmann et al. 2000) and, while being in general low (see list in Keller 1988), they were similar to those measured in the Bay of Biscay (0.0040.049, Morán and Scharek 2015) and comparable to some of the values of the central Atlantic (Kyewalyanga et al. 1998, Marañón and Holligan 1999) and the coast of Japan (Furuya et al. 1998). In the Atlantic, the values were particularly low at low latitudes and in surface waters. In most studies in the Mediterranean Sea, the values of $\alpha^{\mathrm{B}}$ were also low, similar to ours either in winter (Morán and Estrada 2005) or spring (Morán and Estrada 2001, Gutiérrez-Rodríguez et al. 2010, Estrada et al. 2014). Low values of the initial slope of the P-E curve are typical of oligotrophic or high-light-intensity environments (Babin et al. 1996, Sakshaug et al. 1997, Finenko et al. 2002). Nutrients are generally low in Blanes Bay, particularly in summer, and we have repeatedly measured $\mathrm{P}$ deficiency of microbial growth in the area (e.g. Lucea et al. 2005, Pinhassi et al. 2006). In addition, Blanes Bay receives relatively high light intensities, as reflected also in the measured values of $\mathrm{E}_{\mathrm{k}}$.
The initial slope of the P-E curve was significantly correlated with production and, interestingly, was also positively correlated with the abundance of diatoms (Table 2), indicating that phytoplankton composition could be relevant in determining the capacity of the natural communities to use light at sub-saturating levels. The correlation was negative in Morán and Scharek (2015), suggesting that even for a putatively ecologically coherent group, the actual species composition plays a fundamental role in photophysiological responses. In a seasonal study, such as this one, species replacement might be more important than photoacclimation, and we observed little seasonality in the evolution of $\alpha^{\mathrm{B}}$ (Fig 5). Kyewalyanga et al. (1998) found the blue-to-red absorption ratio of phytoplankton to statistically explain $\alpha^{\mathrm{B}}$, and one can assume that changes in this absorption ratio are related to changes in pigment content, and thus to phytoplankton community structure. Additional statistical evidence that the structure of the phytoplankton community also helped in part to explain the measured parameters was obtained by the PCA analyses, but the Mantel tests failed to indicate that the effect of community structure was additional to the effect of the seasonal variations in the environmental parameters.

In Blanes Bay, $\alpha^{\mathrm{B}}$ was not correlated with $\mathrm{P}_{\text {max }}^{\mathrm{B}}$ This has been named " $E_{K}$-dependent variability", when physiological adjustments in response to changing light, i.e. photoacclimation, drive the relationship between production and Chl $a$ (Behrenfeld et al. 2004). In other seasonally studied environments, the two parameters were correlated (Tillmann et al. 2000, Morán and Scharek 2015), yet Morán (2007) observed no correlation between these parameters for the picophytoplankton fraction, but a positive correlation for the large phytoplankton (Morán and Scharek 2015). The positive correlation has been observed at sites dominated by phytoplankton with a larger cell size (Claustre et al. 1997, Basterretxea and Arístegui 2000, Morán and Estrada 2001). We did observe a summer increase in $\mathrm{E}_{\mathrm{k}}$ (the ratio between $\mathrm{P}^{\mathrm{B}}{ }_{\max }$ and alpha) in Blanes Bay, although this was modest (see Fig. 5 and Table 2). Picophytoplankton contribution to total phytoplankton biomass is large in summer (Figs. 2 and 4), and this could explain the lack of correlation observed between the two photophysiological parameters.

Our measured values of $\mathrm{E}_{\mathrm{k}}$ were relatively high, comparable to those from the surface waters of the low-latitude Atlantic Ocean (Marañón and Holligan 1999) but within the limits of other studies (i.e. Morán and Scharek 2015). These relatively high values of $E_{k}$ concur with the relatively low values of $\alpha^{\mathrm{B}}$ and with the light intensity that the communities were receiving in situ. Photoacclimation of the algal communities also explained why we found only two instances of photoinhibition. The latter could probably be explained by deep-water intrusions into the continental shelf, bringing non-adapted communities from deeper waters. These intrusions have been described for the area of Blanes Bay (Masó and Tintoré 1991).

Peeters et al. (1991) suggested that the measured values of $E_{k}$ could be compared with the average ir- 
radiance in the mixed layer (Eav) to detect instances of light limitation of phytoplankton growth. If Eav/ $\mathrm{E}_{\mathrm{k}}$ were $<1$, this would indicate that the algae had the potential for more photosynthesis but there was not enough irradiance reaching the cells. In the Wadden sea Tillmann et al. (2000) observed average values of the ratio well below one. In the Bay of Blanes we observed average values of Eav/ $\mathrm{E}_{\mathrm{K}}=2.3$, summer values above 3 , and values clearly below 1 only in November (0.69), indicating that light was not limiting photosynthesis in the Bay. In fact, the ratio Eav/ $\mathrm{E}_{\mathrm{K}}$ was significantly positively correlated with temperature, transparency and stratification, and negatively correlated with phosphate and silicate concentrations $(\mathrm{r}=-0.8, \mathrm{P}<0.05)$, indicating that when more light is available and less nutrients are present, the irradiance available is enough to meet the needs of the phytoplankton community. Blanes Bay showed clear nutrient deficiency in summer (Fig. 2).

\section{Global seasonality of production}

We observed marked seasonal patterns of total particulate primary production and of Chl $a$-specific production rates, which were remarkably opposed (Pearson $\mathrm{r}=0.41, \mathrm{~N}=114, \mathrm{P}<0.001)$. The seasonal trends are more evident for surface values (Fig. 5C) than for depth-integrated values. Seasonality is a strong force governing the dynamics of temperate coastal environments, and we had previously observed this seasonality in carbon (Alonso-Sáez et al. 2008) and sulfur (Simó et al. 2009) cycling, as well as in microbial community structure (Alonso-Sáez et al. 2007). Here we show that both phytoplankton community structure (Fig. 3), and its function (Fig. 5) also vary strongly seasonally.

As a consequence, the values of the $\mathrm{C}: \mathrm{Chl} a$ ratio also varied strongly with the season (Fig. 4), with values above 80 in summer and around 40-70 in winter. These values are in line to those estimated or measured in other studies (e.g. Arin et al. 2002). Gutiérrez-Rodríguez et al. (2010) estimated C:Chl $a$ values ranging from 34-163 in bloom and non-bloom conditions in the NW Mediterranean and GutiérrezRodríguez et al. (2010) values of 11-135 in Blanes Bay, also with maximum values in summer and minimum in winter. Marañón (2005) calculated values of 100-170 for central Atlantic surface waters and in a recent data review (Marañón et al. 2014) presented average values of 50-117 for a variety of marine ecosystem types. Physiological studies show that this ratio tends to increase when the irradiance is higher and nutrients are low (Geider et al. 1998), explaining the summer maxima at Blanes Bay.

The hourly values of primary production varied by two orders of magnitude $\left(0.07-7 \mathrm{mg} \mathrm{C} \mathrm{m}^{-3} \mathrm{~h}^{-1}\right)$, with an average of $1.45 \pm 0.13$, maximal values in late winter and lower values in summer. The Chl $a$-specific values ranged from 0.05-13 (average, 2.49 $\pm 0.19 \mathrm{mg}$ $\mathrm{C}$ mg Chl $a^{-1} \mathrm{~h}^{-1}$ ), with maximum values in summer. These values are similar to some of those measured in coastal waters of the eastern Mediterranean (e.g. average $0.92 \mathrm{mg} \mathrm{C} \mathrm{m}^{-3} \mathrm{~h}^{-1}$ and $3.6 \mathrm{mg} \mathrm{C} \mathrm{mg} \mathrm{Chl} \mathrm{a}^{-1} \mathrm{~h}^{-1}$ in Azov 1986, Berman et al. 1984) and to those measured in winter in surface water of the NW Mediterranean (Morán and Estrada 2005), and are about one-third of total primary production in the Bay of Biscay (Morán and Scharek 2015). The values measured at Blanes Bay are also slightly lower than those measured in the nearby Banyuls Bay (10 and $70 \mathrm{mg} \mathrm{C} \mathrm{m}^{-3} \mathrm{~d}^{-1}$ ), about $200 \mathrm{~km}$ north in the NW Mediterranean coast (Charles et al. 2005) but with rather similar seasonal trends.

The overall relationship between chlorophyll and primary production had a relatively low global log-log slope (0.53) compared with previous studies (slopes usually >0.7, de Lafontaine and Peters 1986; Baines et al. 1994, Gasol and Duarte 2000; or even $>1$, Marañón et al. 2014). Yet, a closer inspection of the data shows that the global low slope is driven by the summer data and, to a lesser extent, by the spring data. The summer Chl $a$ and production were not significantly related, and at low Chl $a$ values particulate production was maintained at a relatively large value (Fig. 7). These findings contrast with the winter data, in which Chl $a$ and production were related with a $\log$-log slope close to 1 . This varying dependency of primary production on chlorophyll is well known from other sites (e.g. Steele and Baird 1962) and can be related to the higher efficiency of the phytoplankters that dominate the system in the summer, reflected in their higher $\mathrm{P}^{\mathrm{B}}{ }_{\max }$ values and higher light utilization. It also casts doubts on the usage of Chl $a$ as an estimator of production (see also Morán and Scharek 2015), especially in oligotrophic coastal regions such as the one studied here.

\section{Phytoplankton gross growth rates}

The estimated in situ (semi-instantaneous) rates of gross growth of the bulk phytoplankton community (average $0.42 \pm 0.03 \mathrm{~d}^{-1}$, range 0.03-1.3, Table 1) were lower than those measured by the dilution method in Blanes Bay during the period 2003-2007 (range 0.3$1.9 \mathrm{~d}^{-1}$, Gutiérrez-Rodríguez et al. 2011), which also showed a stronger seasonality than the one we observed (Fig. 6). Short-term (few days) variability in growth rates (from 0.1 to $0.8 \mathrm{~d}^{-1}$ ) was observed in the SW Mediterranean Sea by Arin et al. (2002), suggesting that this large variability might end up averaged out in a long-term study such as ours, whereas it might be more evident in a one-per-month, one-year study.

Lignell et al. (2003) found that nutrient-replete growth rates of the whole phytoplanktonic community in the Baltic coastal zone ranged from 0.1 to $0.7 \mathrm{~d}^{-1}$, with small ( 2 to $10 \mu \mathrm{m}$ ) algae growing faster (up to 1.5 $\mathrm{d}^{-1}$ ) than cyanobacteria. Latasa et al. (2005) additionally argued that the relatively high growth rates they measured in summer in the Mediterranean were related to the overwhelming presence of eukaryotes within a community dominated by small phytoplankton. In Blanes Bay in summer, when the growth rates are higher, picophytoplankton dominate the phytoplankton community (Fig. 4), thus agreeing with the study by Lignell et al. (2003), but cyanobacteria dominate among the picophytoplankters (Fig. 3), thus disagreeing with the Latasa et al. study. 


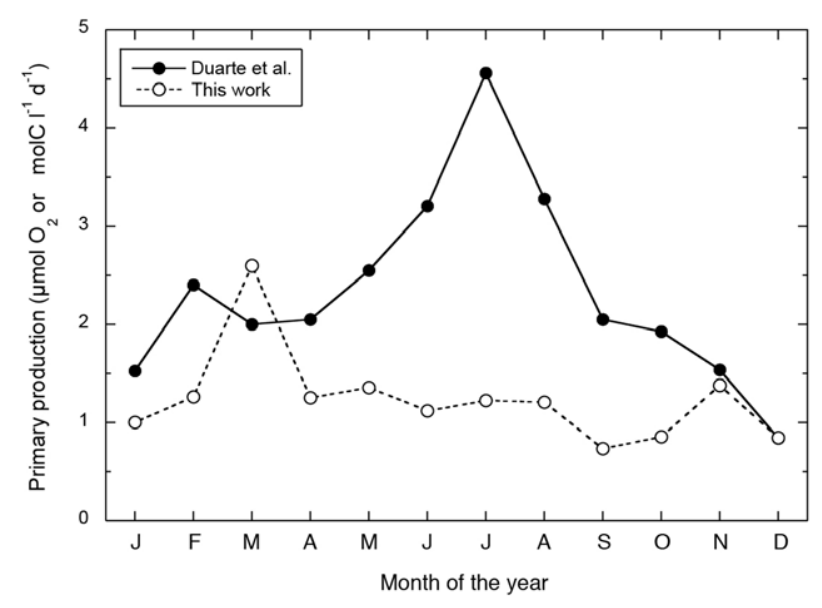

Fig. 8. - Comparison of the seasonal evolution of daily gross primary production determined with the oxygen method (GPP-DO, black symbols) and with ${ }^{14} \mathrm{C}$ incorporation in particular organic carbon $\left({ }^{14} \mathrm{C}-\mathrm{POC}\right.$, white symbols). The GPP-DO data were measured in 1992-1998 and published in Duarte et al. (2004).

The rates of growth observed by Gutiérrez-Rodríguez et al. (2011) with the dilution method in spring and summer were $>1.3 \mathrm{~d}^{-1}$, while in the winter they were $\sim 0.65 \mathrm{~d}^{-1}$, although these are rates integrated through $24 \mathrm{~h}$ of incubation. Using data of ${ }^{14} \mathrm{C}$-based primary production for estimating phytoplankton growth rates has sometimes resulted in much lower values when compared with dilution-growth experiments (Moigis 1999, but see Figure 1 in Kirchman 2016). Marra (2002) proposed that short $(<6 \mathrm{~h})$ radiocarbon incubations would yield production rates closer to net rather than gross growth, yet Latasa et al. (2005) showed a good correspondence between growth rates estimated from primary production and short P-E experiments like the ones used here. Our measured growth rate values are substantially higher than those obtained in the oligotrophic Atlantic by Marañón et al. (2003) ( 0.2 to $\left.0.3 \mathrm{~d}^{-1}\right)$, who also used fractionated ${ }^{14} \mathrm{C}$ uptake and biomass measurements for estimating growth rate, and more similar to those estimated by Marañón (2005) from data compiled for the Atlantic Ocean $\left(0.2-0.5 \mathrm{~d}^{-1}\right)$. There is ample evidence that low nutrient supply, such as that estimated for summer Blanes Bay communities, limits phytoplankton growth. The values we measured were much lower than those measured in nutrient-replete conditions in culture (Cullen et al. 1982). They were also relatively far from the maximum possible according to photophysiology (the rates reached were ca. $70 \%$ of the maximum, Table 1 ). Relatively modest growth rates would concur with the observed values of $\mathrm{P}^{\mathrm{B}}{ }_{\text {max }}$ (average 3.5), and also concur with the relatively high $\mathrm{C}: \mathrm{Chl} a$ values measured in the Bay (average 65.2 \pm 3.7 , summer values ca. 100, Fig. 4).

\section{Global estimates of production}

We measured average values of primary production of $1.45 \pm 0.13 \mathrm{mg} \mathrm{C} \mathrm{m}^{-3} \mathrm{~h}^{-1}$ (Table 1$)$. To calculate depth-integrated yearly-averaged values of production, we used the monthly averages of the photosynthetic parameters, water transparency and surface irradiance to model average monthly values of surface (Fig. 8) and integrated production, accounting for the natural and depth variability in total irradiance and day length. Calculating daily production on the basis of one single surface measurement per day (or one monthly average) implies assuming constant conditions of the main parameters (transparency, Chl $a$, and $\mathrm{P}^{\mathrm{B}}{ }_{\text {max }}$ and $\alpha^{\mathrm{B}}$ ) in the whole water column and throughout the day, when diel variations in the photosynthetic parameters are well documented, spanning over ten-fold across small temporal and spatial gradients (Harding et al. 1982, Côté and Platt 1983, Morán and Estrada 2001), and that $\mathrm{P}^{\mathrm{B}}{ }_{\max }$ and $\alpha^{\mathrm{B}}$ tend to vary predictably along the vertical profile (Morán and Scharek 2015). For our goals of obtaining a rough estimate of annual average production, however, the assumption of monthly-averaged parameters should allow for a reasonable estimate.

The average seasonality of production was much smoother, since summer days are longer and irradiance is higher when production is lower, and this generates an average surface value slightly above $1.2 \mathrm{mg} \mathrm{C} \mathrm{m}^{-3}$ $\mathrm{h}^{-1}$. Considering water transparency, which changes seasonally, and integrating daily (with the changing light during the day) and yearly, this value translated into $48 \mathrm{~g} \mathrm{C} \mathrm{m}^{-2} \mathrm{yr}^{-1}$, equivalent to daily value of 0.13 $\mathrm{g} \mathrm{C} \mathrm{m}^{-2} \mathrm{~d}^{-1}$. This value would be only $7 \%$ larger $(51$ $\mathrm{gC}$ ) if we considered the summer (April-October) stratification of the site (which in general is 2-3 degrees colder in the lower $10 \mathrm{~m}$ than in the first $10 \mathrm{~m}$ ) and we assumed half the value of $\mathrm{P}_{\text {max }}^{\mathrm{B}}$ and double $\alpha^{\mathrm{B}}$ values in the deeper waters, as occurs at other coastal sites (Morán and Scharek 2015).

Coastal stations in the Mediterranean Sea, such as the Bay of Naples (over a deeper water column) or the Adriatic coast, over similar relatively shallow water columns, showed values above those we have measured in Blanes Bay (ca. $150 \mathrm{~g} \mathrm{C} \mathrm{m}^{-2} \mathrm{yr}^{-1}$, Pugnetti et al. 2006). The Bay of Marseille and the Banyuls area also showed higher values ( $88 \mathrm{~g} \mathrm{C} \mathrm{m}^{-2} \mathrm{yr}^{-1}$, Lefevre et al. 1997; and 86-142 $\mathrm{g} \mathrm{C} \mathrm{m}^{-2} \mathrm{yr}^{-1}$, Jacques 1970). Similarly, some old estimates for the Catalan Sea were also higher (76-88 $\mathrm{g} \mathrm{C} \mathrm{m}^{-2} \mathrm{yr}^{-1}$, Margalef and Ballester 1967, Margalef and Castellví 1967). In the classical compilation of Sournia (1973), the values for coastal Mediterranean sites ranged between 30 and $140 \mathrm{~g} \mathrm{C}$ $\mathrm{m}^{-2} \mathrm{yr}^{-1}$, with the lowest values in the eastern Mediterranean. Estrada (1996), on the bases of published data, assumed minimum values of about $80 \mathrm{~g} \mathrm{C} \mathrm{m}^{-2}$ $\mathrm{yr}^{-1}$ for the Catalan coast (but for stations deeper than that at Blanes). Open ocean stations in which production has been measured continuously also show higher values (Dyfamed station, 86-232 $\mathrm{g} \mathrm{C} \mathrm{m}^{-2} \mathrm{yr}^{-1}$, Marty and Chiavérini 2002), although they have always integrated a much deeper water column than the one we integrated (only $20 \mathrm{~m}$ ). In fact, the hourly rates of primary production in Blanes Bay (average $1.45 \mathrm{mg} \mathrm{m}^{-3}$ $\mathrm{h}^{-1}$ ) were similar to the values observed at the surface of the Dyfamed open ocean station (Fig. 6 in Marty and Chiavérini 2002), all of which confirm the true oligotrophic nature of the Blanes Bay site, and its utility as a reference for an oligotrophic NW Mediterranean model site. 


\section{Comparison with values of oxygen-derived gross primary production}

Duarte et al. (2004) investigated community metabolism in the Bay of Blanes during the period 1992-1999 with the oxygen method. The values of gross primary production (GPP) that they measured in winter were higher than but comparable to (assuming a respiratory quotient, RQ of 1) our values of ${ }^{14} \mathrm{C}$ based primary production (Fig. 8), but the summer values were between 2-fold and 3-fold higher (and in July >4fold), coincident with the maximum respiration rates measured in Blanes Bay. Respiration covaried strongly with temperature, and net community production was very negative in summer (Duarte et al. 2004). In a compilation of published values, oxygen-based estimates of GPP were found to be on average 2.2 times higher than ${ }^{14} \mathrm{C}$-based particulate carbon production estimates (Regaudie-de-Gioux et al. 2014), a value similar to the average increase of 2 that we measured. Values derived using ${ }^{14} \mathrm{C}$-POC are thought (Marra 2002) to estimate something near net primary production (NPP, the production available to support phytoplankton growth after accounting for losses due to respiration and excretion) but also include the effects of trophic interactions within the incubated sample and do not account for DOC release, which may account for up to $40 \%$ of total primary production in the NW Mediterranean (Morán et al. 2010) and specifically 45\% in Blanes Bay (Alonso-Sáez et al. 2008); nor do they account for respiratory losses by the whole community, which would be better captured with other methods. On the other hand, oxygen-based estimates are thought to approach GPP (Marra 2002) and are logically higher than the NPP values. It is interesting to note that we found seasonality in the difference between $\mathrm{O}_{2}$-based production and ${ }^{14} \mathrm{C}$-PPp, with larger differences in the warmest months, and that this difference was well related to the mean community respiration measured by Duarte et al. (2004): Ratio GPP/ $/{ }^{14} \mathrm{C}-\mathrm{PPp}=0.69+0.39 \times \operatorname{Resp}, \mathrm{N}=12$, $\mathrm{P}<0.001, \mathrm{r}^{2}=0.49$. In fact, discrepancies between these two estimates have often been identified, especially under conditions of low nutrients, high light, or low $\mathrm{P} / \mathrm{R}$ ratios (Peterson 1980), which are the conditions characterizing Blanes Bay in summer.

\section{CONCLUSION}

A relatively long (12 years) dataset has permitted a reliable characterization of the seasonal variations in the rates of primary production and in their associated photophysiological parameters in the coastal oligotrophic station of Blanes Bay. The data obtained here are consistent with data obtained in similar coastal systems, with a clear succession of phytoplankton groups and of the photosynthesis parameters. We have not yet observed significant long-term trends either in primary production or in the photosynthetic parameters, except in $E_{k}$ as noted, although evidence exists for the last 15 years in chlorophyll levels and bacterial abundances (Sarmento et al. 2010, Gasol et al. 2012). If funding and overall support to long-term marine observatories is continued, the data presented here will serve as the standard to compare future variability, such as the hypothesized change in phytoplankton community structure (e.g. Morán et al. 2010, Acevedo-Trejos et al. 2014), and to identify significant trends in biological processes. By fuelling marine food webs, planktonic primary production is a key ecosystem service provided by coastal seas. The comprehensive temporal scales of variability and the relations with other biotic and abiotic variables shown here should provide the basis for future assessments of the ecosystem services provided by the coastal seas.

\section{ACKNOWLEDGEMENTS}

We thank all members of the Blanes Bay Microbial Observatory sampling team, as well as Anselm, our captain, and his boats Margarita I, Margarita II and Xino-Xano. Research at the BBMO has been supported over time by many projects. We emphasize the EU projects Picodiv (EVK3-CT1999-00021), BASICS (EVK3-CT-2002-00078) and Micro-3B (FP7-OCEAN-2011 287589), and the Spanish projects Estramar, PROCAVIR (CTM2004-06842), MICROVIS (CTM2007-62140), Modivus (CTM2005-04795/ MAR), Gemma (CTM2007-63753-C02-01/MAR), STORM (CTM2009-09352), SUMMER (CTM200803309/MAR) and FLAME (CTM2007-62140). The current work of the authors is supported by the grants Doremi (CTM2012-34294), Pegaso (CTM201237615), MEFISTO (CTM2013-43767-P), ANIMA (CTM2015-65720) and Remei (CTM2015-70340-R), yet sampling is contributed to from the PI's own pocket. We thank Clara Ruiz-González and Guillem Salazar for help with statistical analyses and the reviewers and editors for helpful suggestions.

\section{REFERENCES}

Acevedo-Trejos E., Brandt G., Steinacher M., et al. 2014. A glimpse into the future composition of marine phytoplankton communities. Front. Mar. Sci. 1: 15. http://dx.doi.org/10.3389/fmars.2014.00015

Alonso-Sáez L., Balagué V., Sà E.L., et al. 2007. Seasonality in bacterial diversity in north-west Mediterranean coastal waters: assessment through clone libraries, fingerprinting and FISH. FEMS Microbiol. Ecol. 60: 98-112. http://dx.doi.org/10.1111/j.1574-6941.2006.00276.x

Alonso-Sáez L., Vázquez-Domínguez E., Cardelús C., et al. 2008. Factors controlling the year-round variability in carbon flux through bacteria in a coastal marine system. Ecosystems 11: 397-409. http://dx.doi.org/10.1007/s10021-008-9129-0

Arin L., Morán X.A.G., Estrada M. 2002. Phytoplankton size distribution and growth rates in the Alboran Sea (SW Mediterranean): Short term variability related to mesoscale hydrodynamics. J. Plank. Res. 24: 1019-1033. http://dx.doi.org/10.1093/plankt/24.10.1019

Azov Y. 1986. Seasonal patterns of phytoplankton productivity and abundance in nearshore oligotrophic waters of the Levant Basin (Mediterranean). J. Plankton Res. 8: 41-53. http://dx.doi.org/10.1093/plankt/8.1.41

Babin M., Morel A., Claustre H., et al. 1996. Nitrogen- and irradiance-dependent variations of the maximum quantum yield of carbon fixation in eutrophic, mesotrophic and oligotrophic marine systems. Deep-Sea Res. 43: 1241-1272. http://dx.doi.org/10.1016/0967-0637(96)00058-1

Baines S.B., Pace M.L., Karl D.M. 1994. Why does the relationship between sinking flux and planktonic primary production differ 
between lakes and oceans? Limnol. Oceanogr. 39: 213-226. http://dx.doi.org/10.4319/lo.1994.39.2.0213

Basterretxea G., Arístegui J. 2000. Mesoscale variability in phytoplankton biomass distribution and photosynthetic parameters in the Canary-NW African coastal transition zone. Mar. Ecol. Prog. Ser. 197: 27-40. http://dx.doi.org/10.3354/meps197027

Behrenfeld M.J., Prasil O., Babin M., et al. 2004. In search of a physiological basis for covariations in light-limited and lightsaturated photosynthesis. J. Phycol. 40: 4-25. http://dx.doi.org/10.1046/j.1529-8817.2004.03083.x

Berman T., Townsend D.W., El Sayed S.Z., et al. 1984. Optical transparency, chlorophyll and primary productivity in the Eastern Mediterranean near the Israeli coast. Oceanol. Acta, 7: 367-372.

Børsheim K.Y., Bratbak G. 1987. Cell volume to cell carbon conversion factors for a bacterivorous Monas sp. enriched from seawater. Mar. Ecol. Prog. Ser. 36: 171-175. http://dx.doi.org/10.3354/meps036171

Charles F., Lantoine F., Brugel S., et al. 2005. Seasonal survey of the phytoplankton biomass, composition and production in a littoral NW Mediterranean site, with special emphasis on the picoplanktonic contribution. Estuar. Coastal Shelf Sci. 65: 199-212. http://dx.doi.org/10.1016/j.ecss.2005.06.006

Claustre H., Moline M.A., Prézelin B.B. 1997. Sources of variability in the column photosynthetic cross section for Antarctic coastal waters. J. Geophys. Research- Oceans 102: 25047-25060.

Côté B., Platt T. 1983. Day-to-day variations in the spring- summer photosynthetic parameters of coastal marine phytoplankton. Limnol. Oceanogr. 28: 320-344. http://dx.doi.org/10.4319/lo.1983.28.2.0320

Cullen J.J., Yang X., Macintyre H.L. 1992. Nutrient limitation and marine photosynthesis, In Falkowski P.G., Woodhead A.D. (eds), Primary productivity and biogeochemical cycles in the sea. Plenum, pp. 69-88. http://dx doi oro/10.1007/978-1-4899-0762-2 5

de Lafontaine Y., Peters R.H. 1986. Empirical relationship for marine primary production-the effect of environmental variables. Oceanol. Acta 9: 65-72

Duarte C.M., Agustí S., Vaqué D. 2004. Controls on planktonic metabolism in the Bay of Blanes, northwestern Mediterranean littoral. Limnol. Oceanogr. 49: 2162-2170. http://dx.doi.org/10.4319/1o.2004.49.6.2162

Estrada M. 1996. Primary production in the northwestern Mediterranean. Sci. Mar. 60: 55-64.

Estrada M., Latasa M., Emelianov M., et al. 2014. Seasonal and mesoscale variability of primary production in the deep wintermixing region of the NW Mediterranean. Deep Sea Res. I 94: 45-61. http://dx.doi.org/10.1016/j.dsr.2014.08.003

Field C.B., Behrenfeld M.J., Randerson J.T., et al. 1998. Primary production of the biosphere: integrating terrestrial and oceanic components. Science 281: 237-240. http://dx.doi.org/10.1126/science.281.5374.237

Finenko Z.Z., Churilova T.Y., Sosik H.M., et al. 2002. Variability of photosynthetic parameters of the surface phytoplankton in the Black Sea. Oceanology 42: 53-67.

Furuya K., Hasegawa O., Yoshikawa T., et al. 1998. Photosynthesis-irradiance relationship of phytoplankton and primary production in the vicinity of Kuroshio warm core ring in spring. J. Oceanogr. 54: 545-552. http://dx.doi.org/10.1007/BF02742456

Gallegos C. 2012. Phytoplankton photosynthetic capacity in a shallow estuary: environmental correlates and interannual variation. Mar. Ecol. Progr. Ser. 463: 3-37. http://dx.doi.org/10.3354/meps09850

Gameiro C., Zwolinski J., Brotas V. 2011. Light control on phytoplankton production in a shallow and turbid estuarine system. Hydrobiologia 669: 249-263. http://dx.doi.org/10.1007/s10750-011-0695-3

Gasol J.M., Duarte C.M. 2000. Comparative analyses in aquatic microbial ecology: how far do they go? FEMS Microbiol. Ecol. 31: 99-106. http://dx.doi.org/10.1111/j.1574-6941.2000.tb00675.x

Gasol J.M., Massana R., Simó R., et al. 2012. Blanes Bay (Site 55). In: O’Brien T.D., Li W.K.W., Morán X.A.G. (eds), ICES Phytoplankton and Microbial Ecology Status Report 2010/2012. pp. 138-141.

Geider R.J., Macintyre H.L., Kana T.M. 1998. A dynamic regulatory model of phytoplankton acclimation to light, nutrients and temperature. Limnol. Oceanogr. 43: 679-694.

http://dx doi.org/10.4319/lo.1998.43.4.0679

Guadayol Ò., Peters F., Marrasé C., et al. 2009. Episodic meteorological and nutrient load events as drivers of coastal planktonic ecosystem dynamics: a time series analysis. Mar. Ecol. Prog. Ser. 381: 139-155. http://dx.doi.org/10.3354/meps07939

Gutiérrez-Rodríguez A., Latasa M., Estrada M., et al. 2010. Carbon fluxes through major phytoplankton groups during the spring bloom and post-bloom in the Northwestern Mediterranean Sea. Deep Sea Res. I 57: 486-500. http://dx.doi.org/10.1016/j.dsr.2009.12.013

Gutiérrez-Rodríguez A., Latasa M., Scharek R., et al. 2011. Growth and grazing rate dynamics of major phytoplankton groups in an oligotrophic coastal site. Est. Coast. Shelf Sci. 95: 77-87. http://dx.doi.org/10.1016/j.ecss.2011.08.008

Hansen H., Koroleff F. 1999. Determination of nutrients. In: Grasshoff K., Kremling K., Ehrhardt M. (eds), Methods of Seawater Analysis. Wiley-VCH, Weinheim, pp 159-226. http://dx.doi.org/10.1002/9783527613984.ch10

Harding L.W., Prezelin B.B., Sweeney B.M., et al. 1982. Diel oscillations of the photosynthesis-irradiance (PI) relationship in natural assemblages of phytoplankton. Mar. Biol. 67: 167-178. http://dx.doi.org/10.1007/BF00401282

Jacques G. 1970. Aspects quantitatifs du phytoplancton de Banyulssur-mer (Golfe du Lion). Biomasse et production, 1956-1969. Vie Milieu ser. B 21: 37-102.

Karl D.M., Church M.J. 2014. Microbial oceanography and the Hawaii Ocean Time-series programme. Nat. Rev. Microbiol. 12: 699-713. http://dx.doi.org/10.1038/nrmicro3333

Keller A.A. 1988. An empirical model of primary productivity $\left({ }^{14} \mathrm{C}\right)$ using mesocosm data along a nutrient gradient. J. Plankton Res. 10: $813-834$. http://dx.doi.org/10.1093/plankt/10.4.813

Kirchman D.L. 2016. Growth rate of microbes in the oceans. Ann. Rev. Mar. Sci. 8: 285-309 http://dx.doi.org/10.1146/annurev-marine-122414-033938

Kirk J.T.O. 1994. Light and photosynthesis in aquatic ecosystems. 2nd Ed. Cambridge University Press. http://dx.doi.org/10.1017/CBO9780511623370

Kovać Ž., Platt T., Sathyendranath S., et al. 2016. Recovery of photosynthesis parameters from in situ profiles of phytoplankton production. ICES J. Mar. Sci. 73: 275-285. http://dx.doi.org/10.1093/icesjms/fsv204

Kyewalyanga M.N., Platt T., Sathyendranath S., et al. 1998. Seasonal variations in physiological parameters of phytoplankton across the North Atlantic. J. Plankton Res. 20: 17-42. http://dx.doi.org/10.1093/plankt/20.1.17

Latasa M., Morán X.A.G., Scharek R., et al. 2005. Estimating the carbon flux through main phytoplankton groups in the northwestern Mediterranean. Limnol. Oceanogr. 50: 1447-1458. http://dx.doi.org/10.4319/lo.2005.50.5.1447

Lefevre D., Minas H.J., Minas M., et al. 1997. Review of gross community production, primary production, net community production and dark community respiration in the Gulf of Lions. Deep Sea Res. II 44: 801-832. http://dx.doi.org/10.1016/S0967-0645(96)00091-4

Lignell R., Seppälä J., Kuuppo P., et al. 2003. Beyond bulk properties: Responses of coastal summer plankton communities to nutrient enrichment in the northern Baltic Sea. Limnol. Oceanogr. 48: 189-209. http://dx.doi.org/10.4319/1o.2003.48.1.0189

Lucea A., Duarte C.M., Agustí S., et al. 2005. Nutrient dynamics and ecosystem metabolism in the Bay of Blanes (NW Mediterranean). Biogeochemistry. 73: 303-323. http://dx doi.org/10.1007/s10533-004-0059-4

Mackas D.L., Thomson R.E., Galbraith M. 2001. Changes in the zooplankton community of the British Columbia continental margin, 1985-1999, and their covariation with oceanographic conditions. Can. J. Fish. Aquat. Sci. 58: 685-702. http://dx.doi.org/10.1139/f01-009

Marañón E. 2005. Phytoplankton growth rates in the Atlantic subtropical gyres. Limnol. Oceanogr. 50: 299-310 http://dx.doi.org/10.4319/10.2005.50.1.0299

Marañón E., Holligan P.M. 1999. Photosynthetic parameters of phytoplankton from $50^{\circ} \mathrm{N}$ to $50^{\circ} \mathrm{S}$ in the Atlantic Ocean. Mar. Ecol. Prog. Ser. 176: 191-203. http://dx.doi.org/10.3354/meps176191

Marañón E., Behrenfeld M.J., González N., et al. 2003. High vari- 
ability of primary production in oligotrophic waters of the Atlantic Ocean: uncoupling from phytoplankton biomass and size structure. Mar. Ecol. Prog. Ser. 257: 1-11. http://dx.doi.org/10.3354/meps257001

Marañón E., Cermeño P., Huete-Ortega M., et al. 2014. Resource supply overrides temperature as a controlling factor of marine phytoplankton growth. PloS One 9: e99312. http://dx.doi.org/10.1371/journal.pone.0099312

Margalef R. 1969. Composición específica del fitoplancton de la costa catalano-levantina (Mediterráneo Occidental) en 19621967. Inv. Pesq. 33: 345-380.

Margalef R., Ballester A. 1967. Fitoplancton y producción primaria de la costa catalana, de junio de 1965 a junio de 1966. Inv. Pesq. 31: 165-182.

Margalef R., Castellví J. 1967. Fitoplancton y producción primaria de la costa catalana, de julio de 1966 a julio de 1967. Inv. Pesq. 31: 491-502

Marra J. 2002. Approaches to the measurement of plankton production. In: Williams P.J. leB., Thomas D.N., Reynolds C.S. (eds), Phytoplankton Productivity: Carbon Assimilation in Marine and Freshwater Ecosystems, Oxford, UK, pp. 78-108. http://dx.doi.org/10.1002/9780470995204.ch4

Marty J.C., Chiavérini J. 2002. Seasonal and interannual variations in phytoplankton production at DYFAMED time-series station, northwestern Mediterranean Sea. Deep Sea Res. II 49: 2017-2030.

http://dx.doi.org/10.1016/S0967-0645(02)00025-5

Masó M., Tintoré J. 1991. Variability of the shelf water off the northeast Spanish coast. J. Mar. Syst. 1: 441-450. http://dx.doi.org/10.1016/0924-7963(91)90008-I

Moigis A.G. 1999. Photosynthetic rates in the surface waters of the Red Sea: the radiocarbon versus the non-isotopic dilution method. J. Plankton Res. 22: 713-727. http://dx.doi.org/10.1093/plankt/22.4.713

Montagnes D.J.S., Berges J.A., Harrison P.J., et al. 1994. Estimating carbon, nitrogen, protein, and chlorophyll a from volume in marine phytoplankton. Limnol. Oceanogr. 39: 1044-1060. http://dx.doi.org/10.4319/10.1994.39.5.1044

Morán X.A.G. 2007. Annual cycle of picophytoplankton photosynthesis and growth rates in a temperate coastal ecosystem: a major contribution to carbon fluxes. Aquat. Microb. Ecol. 49: 267-277. http://dx.doi.org/10.3354/ame01151

Morán X.A.G., Estrada M. 2001. Short-term variability of photosynthetic parameters and particulate and dissolved primary production in the Alboran Sea (SW Mediterranean). Mar. Ecol. Prog. Ser. 212: 53-66. http://dx.doi.org/10.3354/meps212053

Morán X.A.G., Estrada M. 2005. Winter pelagic photosynthesis in the NW Mediterranean. Deep-Sea Res. I 52: 1806-1822. http://dx.doi.org/10.1016/j.dsr.2005.05.009

Morán X.A.G., Scharek R. 2015. Photosynthetic parameters and primary production, with focus on large phytoplankton, in a temperate mid-shelf ecosystem, Est. Coast. Shelf Sci. 154: 255-263. http://dx.doi.org/10.1016/j.ecss.2014.12.047

Morán X.A.G., López-Urrutia A., Calvo-Díaz A., et al. 2010. Increasing importance of small phytoplankton in a warmer ocean. Global Change Biology 16: 1137-1144 http//dx doi oro/10.111//1365-2486.2009 01960x

O'Brien T.D. 2012. Time-series data analysis and visualization. In: O’Brien T.D., Li W.K.W., Morán X.A.G. (eds), ICES Phytoplankton and Microbial Ecology Status Report 2010/2012. ICES Cooperative Research Report. pp. 8-19.

Oksanen J., Blanchet F.G., Kindt R., et al. 2016. vegan: Community Ecology Package. R package version 2.3-3 https://CRAN.R-project.org/package=vegan

Ondrusek M.E., Bidigare R.B., Waters K., et al. 2001. A predictive model for estimating rates of primary production in the subtropical North Pacific Ocean. Deep-Sea Res. II 48: 1837-1863. http://dx.doi.org/10.1016/S0967-0645(00)00163-6

Peeters J.C.H., Haas H.A., Peperzak L., et al. 1991. Limiting fac- tors for phytoplankton in the North Sea. Water Sci. Tech. 24: 261-267.

Peterson B.J. 1980. Aquatic primary production and the ${ }^{14} \mathrm{C}-\mathrm{CO}_{2}$ method: a history of the productivity problem. Annu. Rev. Ecol. Syst. 11: 359-385.

http://dx.doi.org/10.1146/annurev.es.11.110180.002043

Pinhassi J., Gómez-Consarnau L., Alonso-Sáez L., et al. 2006. Seasonal changes in bacterioplankton nutrient limitation and their effects on bacterial community composition in the NW Mediterranean Sea. Aquat. Microb. Ecol. 44: 241-252. http://dx.doi.org/10.3354/ame044241

Platt T., Sathyendranath S. 1993. Fundamental issues in measurement of primary production. ICES MSS, 197. 3-8

Platt T., Gallegos C.L., Harrison W.G. 1980. Photoinhibition of photosynthesis in natural assemblages of marine phytoplankton. J. Mar. Res. 38: 687-701.

Pugnetti A., Camatti E., Mangoni O., et al. 2006. Phytoplankton production in Italian freshwater and marine ecosytems: State of the art and perspectives. Chemistry and Ecology 22 Suppl.1, S49-S69 http://dx.doi.org/10.1080/02757540600557330

R Core Team. 2014. R: A language and environment for statistical computing. R Foundation for Statistical Computing, Vienna, Austria. http://www.R-project.org/

Regaudie-de-Gioux A., Lasternas S., Agustí S., et al. 2014. Comparing marine primary production estimates through different methods and development of conversion equations. Front. Mar. Sci. 1: 19 . http://dx.doi.org/10.3389/fmars.2014.00019

Romera-Castillo C., Álvarez-Salgado X.A., Galí M., et al. 2013. Combined effect of light exposure and microbial activity on distinct dissolved organic matter pools. A seasonal field study in an oligotrophic coastal system (Blanes Bay, NW Mediterranean). Mar. Chem. 148: 44-51. http://dx.doi.org/10.1016/j.marchem.2012.10.004

Sakshaug E., Bricaud A., Dandonneau Y., et al. 1997. Parameters of photosynthesis: definitions, theory and interpretation of results. J. Plankton Res. 19: 1637-1670. http://dx.doi.org/10.1093/plankt/19.11.1637

Sarmento H., Montoya J.M., Vázquez-Domínguez E., et al. 2010. Warming effects on marine microbial food web processes: How far can we go when it comes to predictions? Phil. Trans. R. Soc. B 365: 2137-2149. http://dx.doi.org/10.1098/rstb.2010.0045

Simó R., Vila-Costa M., Alonso-Sáez L., et al. 2009. Annual DMSP contribution to $\mathrm{S}$ and $\mathrm{C}$ fluxes through phytoplankton and bacterioplankton in a NW Mediterranean coastal site. Aquat. Microb. Ecol. 57: 43-55. http://dx.doi.org/10.3354/ame01325

Sournia A. 1973. La production primaire planctonique en Mediterranee. Newslett. Coop. Invest. Mediterr. Spec. Issue, No. 5128 pp.

Steele J.H., Baird I.E. 1962. Further relations between primary production, chlorophyll, and particulate carbon. Limnol. Oceanogr. 7: $42-44$ http://dx.doi.org/10.4319/10.1962.7.1.0042

Steeman-Nielsen E. 1952. The use of radioactive carbon for measuring organic production in the sea. J. Cons. Int. Explor. Mer 18: $117-140$ http://dx.doi.org/10.1093/icesjms/18.2.117

Steinberg D.K., Carlson C.A., Bates N.R., et al. 2001. Overview of the US JGOFS Bermuda Atlantic Time-series Study (BATS): a decade-scale look at ocean biology and biogeochemistry. DeepSea Res. II 48: 1405-1447. http://dx.doi.org/10.1016/S0967-0645(00)00148-X

Tillmann U., Hesse K.-J., Colijn F. 2000. Planktonic primary production in the German Waden Sea. J. Plankton Res. 22: $1253-1276$ http://dx.doi.org/10.1093/plankt/22.7.1253

Webb WL., Newton M., Starr D. 1974. Carbon dioxide exchange of Alnus rubra: a mathematical model. Oecologia 17: 281-291. http://dx.doi.org/10.1007/BF00345747 